\title{
The Frontier Formation and Associated Rocks of Northeastern Utah and Northwestern Colorado
}

\section{2nd SET}

\section{U.S. GEOLOGICAL SURVEY BULLETIN 1787-M}

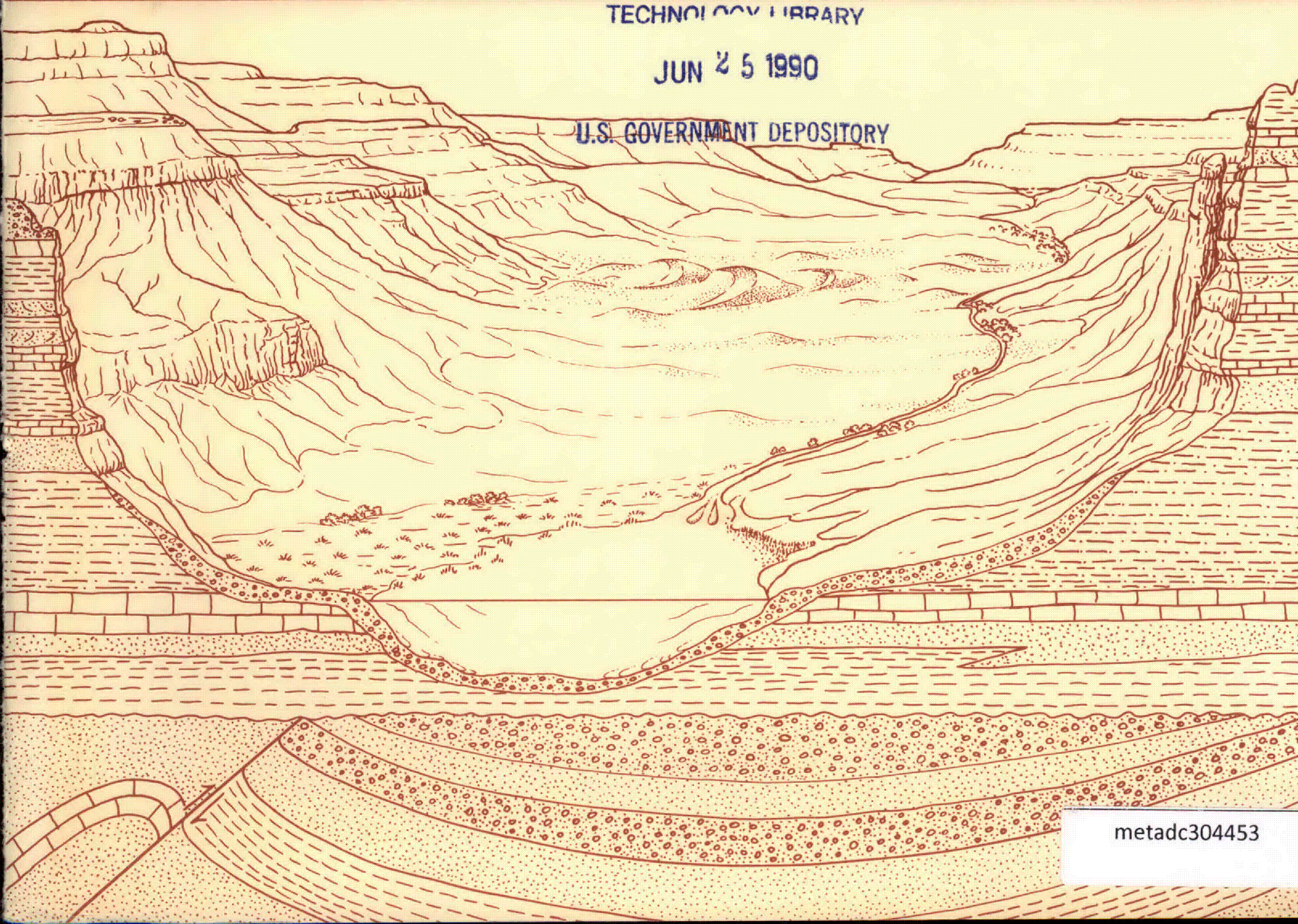


Chapter M

\section{The Frontier Formation and Associated Rocks of Northeastern Utah and Northwestern Colorado}

\section{By C.M. MOLENAAR and B.W. WILSON}

A multidisciplinary approach to research studies of sedimentary rocks and their constituents and the evolution of sedimentary basins, both ancient and modern 


\section{DEPARTMENT OF THE INTERIOR \\ MANUEL LUJAN, JR., Secretary}

\section{U.S. GEOLOGICAL SURVEY}

Dallas L. Peck, Director

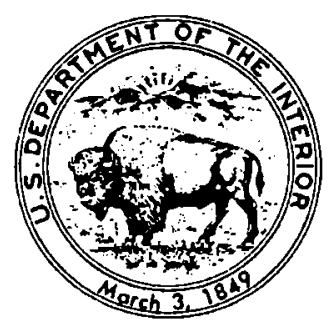

Any use of trade, product, or firm names in this publication is for descriptive purposes only and does not imply endorsement by the U.S. Government.

UNITED STATES GOVERNMENT PRINTING OFFICE: 1990

For sale by the Books and Open-File Reports Section

U.S. Geological Survey

Federal Center

Box 25425

Denver, CO 80225

\section{Library of Congress Cataloging-in-Publication Data}

Molenaar, C. M.

The Frontier Formation and associated rocks of northeastern Utah and northwestern Colorado / by C. M. Molenaar and B. W. Wilson.

p. $\mathrm{cm}$. - (Evolution of sedimentary basins-Uinta and Piceance basins :

ch. M) (U.S. Geological Survey bulletin : 1787-M)

Includes bibliographical references.

Supt. of Docs. no.: I 19.3:1787-M

1. Geology, Stratigraphic-Cretaceous. 2. Geology-Utah

3. Geology-Colorado. 4. Frontier Formation. I. Wilson, B.W.

II. Title. III. Series. IV. Series: U.S. Geological Survey bulletin ; 1787-M.

QE75.B9

[QE688]

$557.3 \mathrm{~s}-\mathrm{dc} 20$

[551.7'7'09792]

$89-600233$ 


\title{
CONTENTS
}

\author{
Abstract M1 \\ Introduction M1 \\ Previous work $\quad$ M3 \\ Methods M3 \\ Stratigraphy M4 \\ Frontier, Mancos, and Mowry terminology M4 \\ Dakota Sandstone and Cedar Mountain Formation M5 \\ Mowry Shale M9 \\ Unnamed shale unit M9 \\ Frontier Formation $\quad$ M10 \\ Basal sandstone M10 \\ Tununk Shale Member M10 \\ Regressive coastal sandstone M11 \\ Nonmarine deposits $\quad$ M11 \\ Transgressive coastal sandstone $\quad \mathbf{M 1 2}$ \\ Offshore-bar sandstone $\quad$ M12 \\ Extent of subaerial-plain deposits (shoreline trend) $\quad$ M13 \\ Discussion M17 \\ Unconformity at base of Frontier Formation $\quad \mathbf{M 1 7}$ \\ Progradational patterns and relative sea level rise $\quad$ M19 \\ References cited $\mathbf{M 2 0}$
}

PLATE

[Plate is in pocket]

1. Stratigraphic correlation sections of the Frontier Formation and associated middle Cretaceous rocks, northeastern Utah and northwestern Colorado.

\section{FIGURES}

1. Map showing outcrops of Frontier Formation and equivalent rocks and extent of subaerial-plain deposits of Frontier Formation, northeastern Utah and northwestern Colorado $\mathrm{M} 2$

2. Chart showing Cenomanian through Coniacian U.S. Western Interior molluscan fossil zones M4

3-4. Stratigraphic correlation section on:

3. South side of Uinta Mountains $\mathbf{M 7}$

4. North side of Uinta Mountains M8

5-6. Photographs showing:

5. Lower part of Frontier Formation unconformably overlying Mowry Shale M9

6. Frontier Formation exposed along Jensen Wash M10

7-8. Cross sections showing correlation and comparison of:

7. Frontier Formation and total marine part of Cretaceous section between Coalville and Red Creek M14

8. Frontier Formation at Red Creek and Ferron Sandstone Member of Mancos Shale at Farnham dome 
9. Map showing distribution and lithofacies of early middle Turonian rocks in the central Rocky Mountains region

\section{TABLES}

1. Control points used in study M5

2. Age-diagnostic fossil collections M6

\section{CONVERSION FACTORS FOR SOME SI METRIC AND U.S. UNITS OF MEASURE}

\begin{tabular}{lll}
\hline \multicolumn{1}{c}{ To convert from } & \multicolumn{1}{c}{ To } & \multicolumn{1}{c}{ Multiply by } \\
\hline Feet $(\mathrm{ft})$ & Meters $(\mathrm{m})$ & 0.3048 \\
Miles $(\mathrm{mi})$ & Kilometers $(\mathrm{km})$ & 1.609 \\
Pounds $(\mathrm{lb})$ & Kilograms $(\mathrm{kg})$ & 0.4536 \\
Degrees Fahrenheit $\left({ }^{\circ} \mathrm{F}\right)$ & Degrees Celsius $\left({ }^{\circ} \mathrm{C}\right)$ & Temp ${ }^{\circ} \mathrm{C}=\left(\right.$ temp $\left.{ }^{\circ} \mathrm{F}-32\right) / 1.8$ \\
\hline
\end{tabular}




\title{
The Frontier Formation and Associated Rocks of Northeastern Utah and Northwestern Colorado
}

\author{
By C.M. Molenaar ${ }^{1}$ and B.W. Wilson ${ }^{2}$
}

\begin{abstract}
The Frontier Formation of the Mancos Group in northeastern Utah and northwesternmost Colorado (proposed new rank designations; formerly known as the Frontier Sandstone Member of the Mancos Shale) consists of several facies of marine and nonmarine rocks of Late Cretaceous (Turonian) age that grade eastward into totally marine rocks in easternmost Utah and northwestern Colorado. The Mancos Group in the report area is divided into the Mowry Shale, an unnamed shale unit, the Frontier Formation, and the main body. Six major facies, some of which are only in parts of the report area, are recognized in the Frontier. In ascending order, these are: (1) a basal, transgressive marine sandstone; (2) a marine shale tongue that correlates with the Tununk Member of the Mancos Shale in central Utah and is here recognized as a member of the Frontier; (3) a prograding coastal sandstone; (4) a sequence of nonmarine sandstone, shale, and coal; (5) an upper, transgressive coastal sandstone; and (6) an offshore-bar sandstone. Along the south flank and along the north flank of the eastern part of the Uinta Mountains, these rocks range in thickness from $760 \mathrm{ft}(232$ $\mathrm{m}$ ) on the west to $140 \mathrm{ft}(43 \mathrm{~m})$ on the east. A lower Turonian transgressive sandstone at the base of the Frontier unconformably overlies an unnamed Cenomanian shale unit in the southwestern part of the Uinta Mountains area. Elsewhere around the Uinta Mountains, an upper middle Turonian shale member of the Frontier unconformably overlies the lower Cenomanian Mowry Shale (proposed new rank designation; formerly known as Mowry Member of Mancos Shale in all but the Utah part of the north flank of the Uinta Mountains). Apparently the intervening Turonian rocks onlap from west to east. After deposition of the basal shale member of the Frontier, a deltaic wedge prograded eastward and southeastward to the vicinity of Split Mountain east of
\end{abstract}

\footnotetext{
${ }^{1}$ U.S. Geological Survey, Box 25046, MS 940, Federal Center, Denver, CO 80225.

${ }^{2}$ Deceased.

Manuscript approved for publication June 30, 1989.
}

Vernal, Utah, and Vermillion Creek in northwesternmost Colorado. The shoreline trend of the deltaic wedge was about N. $60^{\circ} \mathrm{E}$. across the eastern Uinta Mountains but probably swung abruptly to the northwest in Wyoming north of the mountains. To the southwest, the shoreline trend was about N. $55^{\circ}$ E. across the Uinta basin. A $100-$ to $200-\mathrm{ft}$ $(30-60 \mathrm{~m})$ relative sea-level rise resulted in deposition of a transgressive shale and overlying offshore-bar sandstone at the top of the Frontier in the eastern part of the area. The offshore-bar and underlying shoreface-equivalent sandstones extend far to the east in Colorado as offshore-shelf units of thinly bedded sandstone and shale.

Correlation of the Frontier Formation near the Uinta Mountains with the 7,800-ft-thick $(2,377 \mathrm{~m})$ Frontier Formation near Coalville, Utah, in the overthrust belt to the northwest, indicates great depositional thickening at Coalville, where both older and younger rocks are included in the Frontier. At Farnham dome southeast of Price, Utah, on the south side of the Uinta basin, the Frontier is represented by the much thinner, totally marine, upper middle Turonian Ferron Sandstone Member of the Mancos Shale.

\section{INTRODUCTION}

The Frontier Formation of northeastern Utah and northwesternmost Colorado (proposed new rank designation; formerly known as the Frontier Sandstone Member of the Mancos Shale) consists of marine and nonmarine rocks of Late Cretaceous (Turonian) age that grade to totally marine rocks in easternmost Utah and northwestern Colorado. Outcrops of the Frontier and underlying rocks along the south flank of the Uinta Mountains and along the north flank of the eastern part (fig. 1) provide data with which to map and correlate the different facies of the Frontier and to project these facies into the adjacent subsurface. The purpose of this report is (1) to describe and correlate outcrop sections of the Frontier and adjacent formations on both sides of the 


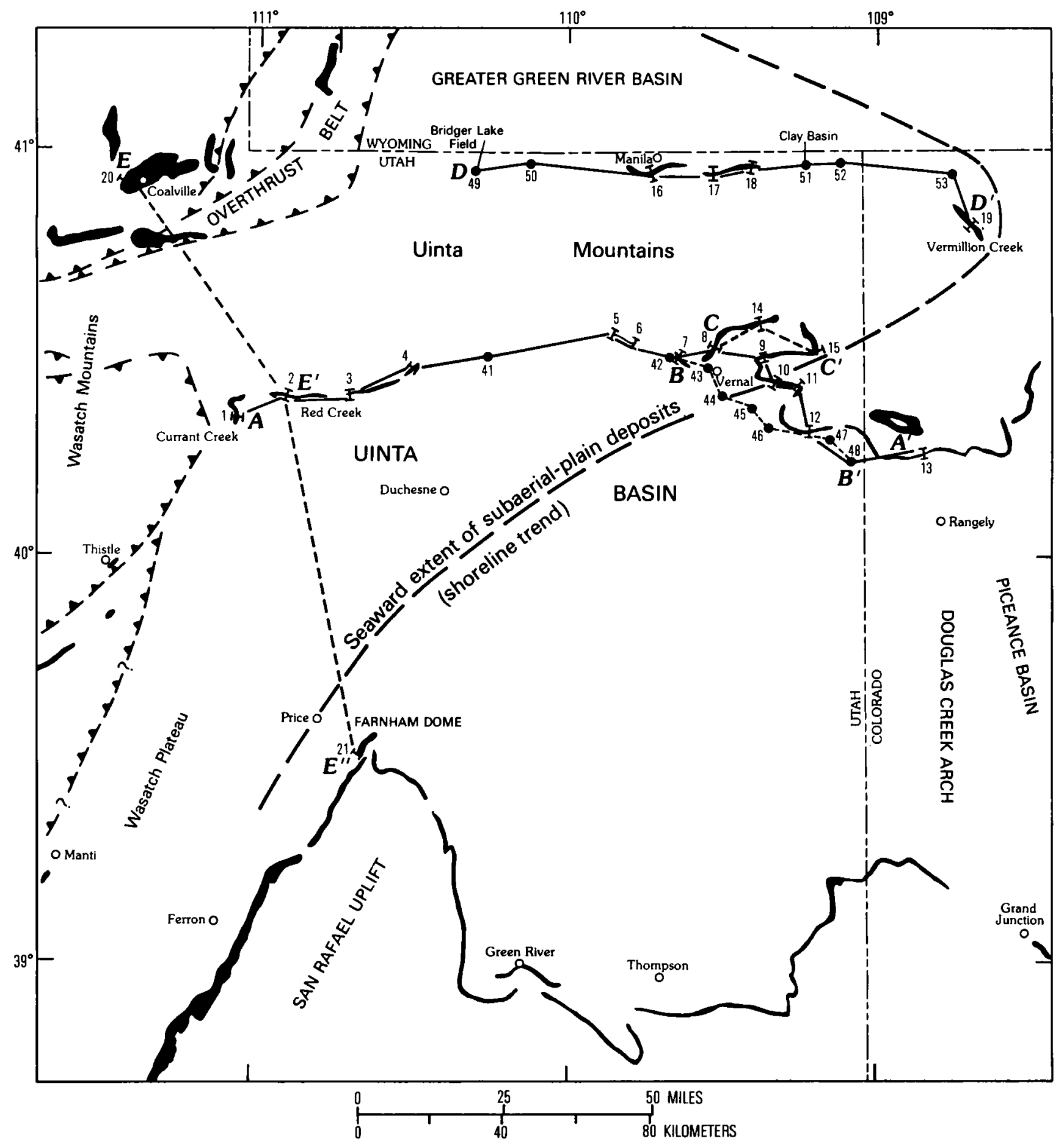

Figure 1. Outcrops of Frontier Formation and equivalent rocks (solid) and extent of subaerial-plain deposits of Frontier Formation, northeastern Utah and northwestern Colorado. Locations of outcrop sections and drill holes used in study and locations of cross sections (plate 1, figs. $3-4,7-8$ ) are also shown.

Uinta Mountains, showing facies relations and biostratigraphic zonation; (2) to compare regional relations of the Frontier on the south side of the mountains with those of the Frontier Formation of the Coalville area in north-central Utah and with those of the Ferron Sandstone Member of the Mancos Shale on the south side of the Uinta basin; and (3) to delineate the shoreline trend of the Frontier across the Uinta basin at the time of maximum progradation.

Most of the field work for this investigation was done in 1967 while the authors were employed by Shell Oil Company. The biostratigraphy of the rocks studied, 
determined mainly from molluscan fossils, is based on published data, fossils collected by the authors, later collections by Molenaar, E.A. Merewether, and W.A. Cobban, and unpublished data by Cobban and Merewether (U.S. Geological Survey, Denver, Colo.). Cobban identified all the molluscan fossils except for a few from the Coalville area. All age-diagnostic fossils were related to the latest sequence of Western Interior index fossils established by Cobban (fig. 2). In addition, foraminiferal data from Shell Oil Company were used to determine the age of strata in a few areas.

Acknowledgments.-Special acknowledgment is extended to coauthor B.W. Wilson, who died in a helicopter accident in 1976 in Alaska. His understanding and experience in examining and interpreting clastic sedimentary sequences added greatly to this report. Most of the field work for this investigation was done in 1967, when the authors were employed by Shell Oil Company. The foraminiferal paleontology referred to in the text was supplied by the late L.D. Holcomb, also with Shell. The Shell Oil Company is gratefully acknowledged for their permission to publish this information. W.A. Cobban identified all molluscan fossils except for a few samples from the Coalville area and provided the data for an updated molluscan fossil zone chart of the lower part of the Upper Cretaceous of the U.S. Western Interior. In addition, E.A. Merewether and W.A. Cobban are thanked for their help in collecting fossils from several of the sections and for pertinent data from their unpublished fossil collections. E.A. Merewether and W.A. Cobban reviewed the manuscript; the report benefited from their constructive criticisms.

\section{PREVIOUS WORK}

Surprisingly few reports have been published on the stratigraphy of the Frontier Formation in the Uinta Mountains area. Walton (1944) described the regional relations of Cretaceous rocks of the Uinta basin including the Frontier along the south flank of the Uinta Mountains. Cobban and Reeside (1952) included the Frontier on the south side of the Uinta Mountains in their discussion of regional relations of the Frontier Formation of Wyoming. Weimer (1962) made subsurface correlations of the Upper Jurassic through Middle Cretaceous rocks (including the Frontier) in south-central Wyoming and northwestern Colorado, primarily around the east plunge of the Uinta Mountains. Hale and Van de Graaff (1964) showed regional correlations for the total Cretaceous section, including the Frontier, in northeastern Utah and adjacent areas. Hansen (1965) mapped and described the Frontier Formation as well as other rocks on the north side of the Uinta Mountains in northeasternmost Utah. Maione (1971) described and correlated the Frontier from the
Vernal area in northeastern Utah eastward into northwestern Colorado. His correlations are similar to those of this study, although there are minor differences. Doelling and Graham (1972) reported on the coal in the Frontier and included several measured sections of the formation. Merewether (1983), Merewether and others (1984), and Merewether and Cobban (1986) showed the correlation of the Frontier Formation of Wyoming with the Frontier on the north side of the Uinta Mountains in northeasternmost Utah and northwesternmost Colorado. In addition, Merewether and Cobban (1986) showed the regional lithofacies patterns of different parts of the Frontier and age-equivalent rocks throughout Colorado, Wyoming, much of Utah, and the southern part of Montana. Ryer and Lovekin (1986), using widely spaced drill-hole logs and published outcrop studies, speculated on the relations between the unconformity at the base of the Frontier and the Vernal delta (the prograding clasticwedge part of the Frontier) and tectonics of the ancestral Uinta Mountains.

\section{METHODS}

For this study, 18 stratigraphic sections of the Frontier Formation and associated strata were measured and described by the authors along the outcrop belt around the Uinta Mountains (fig. 1). An additional section at Vermillion Creek is from Reeside (1955). Exposures in the eastern half of the study area are much better and more abundant than those in the western half; outcrops in the western part are at higher elevations and are restricted by vegetation. All sections were measured with a Jacob's staff; the accuracy of thicknesses and differentiation of facies were emphasized. Except at Currant Creek (control point 1), in the western part of the area, errors in thickness measurements are probably less than 10 percent of the correct thickness. In some cases, however, measured thicknesses of shale sections in outcrops, especially where steeply dipping, are greater than indicated by nearby drill holes. This is thought to be due to expansion of shale sections in surface exposures as a result of release of confining pressure or possibly to minor repetition of section by undetected, small limbthrust faults. At Currant Creek, discontinuous exposures, covered intervals, and possible structural complications associated with folding and faulting of the thrust belt (fig. 1) preclude accurately measured thicknesses.

Except for thinly interbedded or intermixed lithologies, the surface sections presented graphically are essentially grain-size plots (plate 1). Even at the reduced scale, the plots clearly depict fining-upward or coarsening-upward depositional units. Because the finer grained sandstones are generally more argillaceous, the grain-size plots are similar to idealized spontaneous 


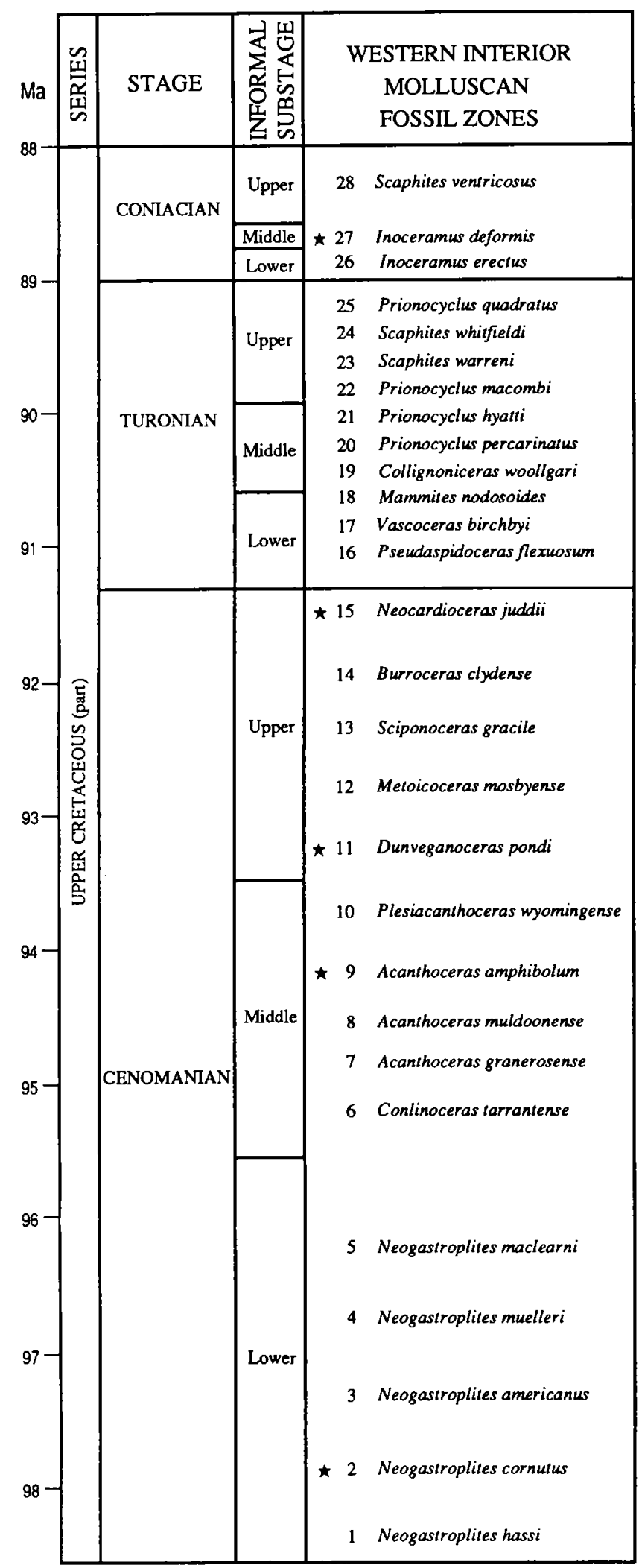

potential logs of drill holes. The crossbed dip directions shown in the graphic columns were those observed while measuring the section. They are not the results of a thorough investigation of paleocurrent directions.
Figure 2 (facing column). Cenomanian through Coniacian (lower Upper Cretaceous) U.S. Western Interior molluscan fossil zones. Zone fossil data from W.A. Cobban (oral commun., 1989) and Cobban and Kennedy (1989). Stars indicate sequential location of rocks radiometrically dated by Obradovich and Cobban (1975) and by J.D. Obradovich (oral commun., 1989).

In areas where outcrop sections are widely spaced along lines of sections, drill-hole logs were used, where available. In addition to the outcrop correlation sections, one subsurface correlation section that parallels an outcrop cross section is included for comparison. Although outcrop sections are much better for interpreting details of lithology, contacts, and bedding features, subsurface sections are better for measuring thicknesses and correlating marker beds in shale sections to show lateral relations of subjacent lithologic units. Thus, the two types of sections complement each other.

Table 1 lists locations of all measured outcrop (numbers 1-21) and drill-hole log (numbers 41-53) sections.

\section{STRATIGRAPHY}

Although the emphasis of this report is on the Frontier Formation of early Late Cretaceous age, depositional relations with underlying and overlying formations are important in interpreting relations within the Frontier. Almost all the measured sections and all drill-hole logs used (fig. 1) include the underlying Mowry Shale (terminology to be discussed) of early Cenomanian age and some include the Dakota Sandstone and Cedar Mountain Formation of Early Cretaceous age. In addition, an unnamed marginal-marine shale unit of probable Cenomanian age separates the Frontier Formation from the underlying Mowry Shale in the western part of the Uinta Mountains. Plate 1 shows details of the measured sections and drill-hole logs including formational relations, biostratigraphic control, and facies relations within the Frontier across segments of the study area. Table 2 lists the pertinent agediagnostic megafossils from the collections indicated on or near the measured sections. Figures 3 and 4 are condensations of the detailed sections showing the overall correlations across the area. Discussions of formational units follow the discussion of proposed formal terminology changes for the Frontier, Mowry, and Mancos.

\section{Frontier, Mancos, and Mowry Terminology}

Both the Frontier Formation and Mowry Shale have formational rank in the Utah portion of the north 
Table 1. Control points used in study

[Shown by number on figure 1 and plate 1. All control points in Utah except for three in Moffat County, Colo.]

\begin{tabular}{|c|c|c|c|}
\hline $\begin{array}{l}\text { Cont } \\
\text { point }\end{array}$ & Name & Location & County \\
\hline & OUTCROP SEC & TONS & \\
\hline 1 & Currant Creek & $\begin{array}{l}\text { NE/4 sec. } 36 . \text { T. } 1 \text { S., R. } 11 \text { W. } \\
\text { NE/4 sec. } 1 \text {, T. } 2 \text { S., R. } 1 \text { W. }\end{array}$ & Wasatch \\
\hline 2 & Red Creek & SW/4 sec. 16, T. 1 S., R. 9 W. & Wasatch \\
\hline 3 & Farm Creek & SW/4 sec. 12, T. 1 S., R. 8 W. & Duchesne \\
\hline 4 & Pigeon Water Creek & SE/4 sec. 24, T. 1 N., R. 6 W. & Duchesne \\
\hline 5 & Grouse Creek & SW/4 sec. 13, T. 3 S., R. 18 E. & Uintah \\
\hline 6 & Deep Creek & SE/4 sec. 27, T. 3 S., R. 19 E. & Uintah \\
\hline 7 & Coal Mine Basin & NE/4 sec. 3, T. 4 S., R. 20 E. & Uintah \\
\hline 8 & Steinaker Reservoir & SE/4 sec. 35, T. 3 S., R. 21 E. & Uintah \\
\hline 9 & Jensen Wash & SE/4 sec. 6, T. 4 S., R. 23 E. & Uintah \\
\hline 10 & Dinosaur National Monument-W & SW/4 sec. 27, T. 4 S., R. 23 E. & Uintah \\
\hline 11 & Dinosaur National Monument-E & SE/4 sec. 31, T. 4 S., R. 24 E. & Uintah \\
\hline 12 & Cliff Creek & W/2 sec. 9, T. 6 S., R. 24 E. & Uintah \\
\hline 13 & Blue Mountain & SE/4 sec. 5, T. 3 N., R. 102 W. & Moffat \\
\hline 14 & Donkey Flat & NW/4 sec. 12, T. 3 S., R. 22 E. & Uintah \\
\hline 15 & McKee Spring & SW $/ 4$ sec. 35, T. 3 S., R. 24 E. & Uintah \\
\hline 16 & Manila & C sec. 36, T. 3 N., R. 19 E. & Daggett \\
\hline 17 & Chokecherry Draw & SE $/ 4$ sec. 34, T. 3 N., R. 21 E. & Daggett \\
\hline 18 & Antelope Flat & NW/4 sec. 27, T. 3 N., R. 22 E. & Daggett \\
\hline 19 & Vermillion Creek & T.10 N., R. $101 \mathrm{~W}$. & Moffat \\
\hline 20 & Coalville & T. 3 N., R. 5 E. & Summit \\
\hline 21 & Famham dome & SW $/ 4$ sec. 15, T. 15 S., R. 11 E. & Carbon \\
\hline & DRILL-HOLE I & OGS & \\
\hline 41 & Gulf Oil Co. Cottonwood Wash Tribal No. 1 & Sec. 7, T. 1 N., R. 3 W. & Duchesne \\
\hline 42 & Bow Valley Expl. (US) Inc. Govt. No.1 & Sec. $4, T .4$ S., R. 20 E. & Uintah \\
\hline 43 & Mayo Utah Oil Co. Asher-Markley No.1 & Sec. 22, T. 4 S., R. $21 \mathrm{E}$. & Uintah \\
\hline 44 & Pioneer Oil Co. Calif. Utah Slaugh No. 1 & Sec. 12 , T. 5 S., R. 21 E. & Uintah \\
\hline 45 & Equity Oil Co. Ashley Valley 1-E. & Sec. 23, T. 5 S., R. 22 E. & Uintah \\
\hline 46 & Avance Oil and Gas Co. Allied Fed. No. 1 & Sec. 5 , T. 6 S., R. 23 E. & Uintah \\
\hline 47 & West Toledo Mine Co. Grethe No. 1 & Sec. 12 , T. 6 S., R. 24 E. & Uintah \\
\hline 48 & New World Oil Co. Max Pray Govt. No. 1 & Sec. 3, T. 7 S., R. 25 E. & Uintah \\
\hline 49 & Phillips Oil Corp. Fork "A" No. 8 & Sec. 36 , T. 3 N., R. 14 E. & Summit \\
\hline 50 & Mobil Oil Corp. Gregory F44-21-P & Sec. 21, T. 3 N., R. 16 E. & Uintah \\
\hline 51 & Mountain Fuel Supply Co. Clay Basin Unit No. 14 & Sec. 20 , T. 3 N., R. 24 E. & Daggett \\
\hline 52 & Pure Oil Co. USA-29 & Sec. 29 T. 3 N. R. 25 E. & Uintah \\
\hline 53 & Mountain Fuel Supply Co. Sugarloaf Unit No.1 & Sec. $4, T .11$ N., R. $101 \mathrm{~W}$. & Moffat \\
\hline
\end{tabular}

side of the Uinta Mountains (Hansen, 1965) and all areas to the north (Cobban and Reeside, 1952; Merewether, 1983; Merewether and others, 1984; Merewether and Cobban, 1986). Both units, however, have been considered members of the Mancos Shale in the Colorado portion of the north flank of the mountains (Sears, 1924; Reeside, 1955; Rowley and others, 1985) and all areas along the south flank (Walton, 1944; Cobban and Reeside, 1952; Kinney, 1955; Maione, 1971; Rowley and others, 1985), although many authors consider them as formations (Stokes and Madsen, 1961; Hale and Van de Graaff, 1964; Doelling and Graham, 1972; Uyger and Picard, 1985; Ryer and Lovekin, 1986). Because both the Frontier and Mowry are widespread, distinctive mappable units and in order to conform to their rank on the north side of the Uinta Mountains, we herein propose to elevate them to formational rank, the Frontier Formation and Mowry Shale. The Mancos is raised to group rank in the report area where it is divided into, in ascending order, the Mowry Shale, an unnamed shale unit, the Frontier Formation, and the main body. This terminology thus applies to all areas on the north sides of the Uinta and Piceance basins where the Mancos terminology is used. The Mowry Shale pinches out south of these areas (Hale and Van de Graaff, 1964) and Frontier terminology is no longer used. On the north side of the Uinta Mountains, the thick Mancos-equivalent shales above the Frontier are assigned to the Hilliard Shale in Utah (Hansen, 1965); in Colorado, these shales are assigned to the main body of the Mancos Group, as they are on the south flank.

\section{Dakota Sandstone and Cedar Mountain Formation}

Basal rocks of the Cretaceous System in the Uinta Mountains area are the Dakota Sandstone and 
Table 2. Age-diagnostic fossil collections

[First number (underlined) of collection refers to fossil zone shown in figure 2. Second number is collection number keyed to figures 7 and 8 and plate 1. Location is in section, township, and range; all localities in Utah except those in Moffat County, Colo.]

\begin{tabular}{|c|c|c|c|c|}
\hline $\begin{array}{l}\text { Fossil zone } \\
\text { and } \\
\text { collection }\end{array}$ & $\begin{array}{l}\text { e USCS } \\
\text { Mesozoic } \\
\text { locality }\end{array}$ & Location & County & Age-diagnostic fossil and reference (if applicable) \\
\hline $21-1$ & D9295 & SE/4 sec. 13, T. 1 S. R,11 W. & Wasatch & Inoceramus n. sp. \\
\hline $13 / 19-2$ & $\begin{array}{l}\text { D12799 } \\
\text { D12797 }\end{array}$ & $\begin{array}{l}\text { NE/4 sec. } 1, \text { T. } 2 \text { S., R. } 11 \mathrm{~W} \text {. } \\
\text { S/2 sec. } 16, \text { T. } 1 \text { S., R. } 9 \text { W. }\end{array}$ & $\begin{array}{l}\text { Wasatch } \\
\text { Wasatch }\end{array}$ & $\begin{array}{l}\text { Inoceramus n. sp } \\
\text { Pycnodonte aff. P. newberryi (Stanton) }\end{array}$ \\
\hline 18-3 & D11042 & SW/4 sec. 12, T. 1 S., R. 8 W. & Duchesne & Mytiloides mytiloides (Mantell)? \\
\hline $13 / 12-4$ & $\begin{array}{l}\text { D12793 } \\
\text { D12794 }\end{array}$ & $\begin{array}{l}\text { W/2 sec. 7. T. } 1 \text { S., R. } 7 \text { W. } \\
\text { W/2 sec. 7, T. } 1 \text { S., R. } 7 \text { W. }\end{array}$ & $\begin{array}{l}\text { Duchesne } \\
\text { Duchesne }\end{array}$ & $\begin{array}{l}\text { Mytiloides cf. M. columbianus (Heinz) } \\
\text { Pycnodonte aff. P. newberryi (Stanton) }\end{array}$ \\
\hline $21-5$ & D9294 & NW/4 sec. 9, T. 1 S., R. 7 W. & Duchesne & Prionocyclus hyatti (Stanton), Inoceramus sp. \\
\hline $24-6$ & D12651 & SE/4 sec. 24 , T. 1 N., R. 6 W. & Duchesne & Inoceramus perplexus Whitfield \\
\hline $24-7$ & D11041 & NE/4 sec. 3, T. 4 S., R. 20 E. & Uintah & Prionocyclus novimexicanus (Marcou) \\
\hline 3-8 & 25586 & Steinaker Draw & Uintah & Neogasiroplites americanus (Reeside and Cobban, 1960) \\
\hline $21-9$ & D9292 & SE/4 sec. 35, T. 3 S., R. 21 E. & Uintah & Lopha bellaplicata (Shumard) \\
\hline $23-10$ & $\begin{array}{l}\text { D } 9290 \\
\text { D } 9293\end{array}$ & $\begin{array}{l}\text { SW/4 sec. } 24, \text { T. } 3 \text { S., R. } 21 \text { E. } \\
\text { SE } / 4 \text { sec. } 35, \text { T. } 3 \text { S., R. } 21 \text { E. }\end{array}$ & $\begin{array}{l}\text { Uintah } \\
\text { Uintah }\end{array}$ & $\begin{array}{l}\text { Prionocyclus hyatti (Stanton), Lopha bellaplicata (Shumard) } \\
\text { Scaphites warreni Meek and Hayden, Inoceramus dimidius White }\end{array}$ \\
\hline $23-11$ & D11040 & SE/4 sec. 6, T. 4 S., R. 23 E. & Uintah & Prionocyclus wyomingensis Meek, Scaphites sp., Inoceramus dimidius White \\
\hline $3-12$ & D11039 & NE/4 sec. 26, T. 4 S., R. 22 E. & Uintah & Prionocyclus wyomingensis Meek, Scaphites warreni Meek and Hayden \\
\hline $23-13$ & D11038 & SE/4 sec. 27, T. 4 S., R. 23 E. & Uintah & Prionocyclus wyomingensis Meek, Inoceramus dimidius White \\
\hline $22-14$ & D12653 & SE/4 sec. 31, T. 4 S., R. 24 E. & Uintah & Inoceramus n. sp., Lopha lugubris (Conrad)? \\
\hline $24-15$ & D12652 & SE/4 sec. 31, T. 4 S., R. 24 E. & Uintah & $\begin{array}{l}\text { Scaphites whitfieldi Cobban, Inoceramus perplexus Whitfield, Prionocyclus } \\
\text { sp. }\end{array}$ \\
\hline 21-16 & D12788 & SW/4 sec. 9. T. 6 S., R. 24 E. & Uintah & Prionocyclus hyatti (Stanton), Inoceramus cuvieri (Sowerby) \\
\hline$\overline{22}-17$ & D11037 & SE/4 sec. 8, T. 6 S., R. 24 E. & Uintah & Prionocyclus macombi Meek \\
\hline & D11036 & SW/4 sec. 9, T. 6 S., R. 24 E. & Uintah & $\begin{array}{l}\text { Prionocyclus wyomingensis Meek, Inoceramus dimidius Whi } \\
\text { lugubris (Conrad) }\end{array}$ \\
\hline 22-18 & D11033 & SE/4 sec. 5, T. 3 N., R. 102 W. & Moffat & Prionocyclus macombi Meek, Inoceramus dimidius White \\
\hline 22-19 & $\begin{array}{l}\text { D12785 } \\
\text { D12786 }\end{array}$ & $\begin{array}{l}\text { NW/4 sec. } 6, \text { T. } 3 \text { N., R. } 100 \text { W. } \\
\text { NW/4 sec. } 6, \text { T. } 3 \text { N., R. } 100 \text { W. }\end{array}$ & $\begin{array}{l}\text { Moffat } \\
\text { Moffat }\end{array}$ & $\begin{array}{l}\text { Lopha lugubris (Conrad } \\
\text { Prionocyclus macombi Meek, Inoceramus dimidius White }\end{array}$ \\
\hline $24-20$ & D11034 & Sec. 5, T. 3 N., R. 102 W. & Moffat & $\begin{array}{l}\text { Scaphites ferronensis Cobban, Prionocyclus wyomingensis Meek, } \\
\text { Inoceramus dimidius White }\end{array}$ \\
\hline $24-21$ & D11035 & SE/4 sec. 5, T. 3 N., R. 102 W. & Moffat & Scaphites whitfieldi Cobban, Inoceramus perplexus Whitfield \\
\hline $21-22$ & $\begin{array}{l}\text { D8873 } \\
\text { D12791 }\end{array}$ & $\begin{array}{l}\text { SE/4 sec. } 5 \text {, T. } 3 \text { N., R. } 102 \text { W. } \\
\text { C sec. } 36, \text { T. } 3 \text { N., R. } 19 \text { E. }\end{array}$ & $\begin{array}{l}\text { Moffat } \\
\text { Daggett }\end{array}$ & $\begin{array}{l}\text { Prionocyclus wyomingensis Meek } \\
\text { Inoceramus n. sp. }\end{array}$ \\
\hline $21-23$ & D9287 & SE $/ 4$ sec. 34, T. 3 N., R. 21 E. & Daggett & Inoceramus aff. I. howelli White \\
\hline $22 / 23-24$ & D9288 & $\mathrm{NE} / 4$ sec. $34, \mathrm{~T} .3$ N., R. $21 \mathrm{E}$. & Daggett & Inoceramus dimidius White \\
\hline$\overline{24}-\overline{25}$ & D9289 & NE/4 sec. 34, T. 3 N., R. 21 E. & Daggett & Inoceramus n. sp., Plicatula? sp. \\
\hline$\underline{23} \underline{\underline{24}-26}$ & D9285 & SW/4 sec. 30, T. 3 N., R. 22 E. & Daggett & Prionocyclus sp., Inoceramus n. sp. \\
\hline 24-27 & D9284 & SW/4 sec. 30, T. 3 N., R. 22 E. & Daggett & Prionocyclus wyomingensis Elans Haas, Inoceramus perplexus Whitfield \\
\hline 2-28 & 26223 & SW/4 sec. 29, T. 3 N., R. 22 E. & Daggett & Neogastroplites cornutus (Reeside and Cobban, 1960) \\
\hline $21-29$ & D12789 & NW/4 sec. 27, T. 3 N., R. 22 E. & Daggett & $\begin{array}{l}\text { Prionocyclus hyatti (Stanton), Inoceramus cuvieri Sowerby, Inoceramus cf. } \\
\text { I. lamarcki Parkinson }\end{array}$ \\
\hline 24-30 & D12790 & NW/4 sec. 27, T. 3 N., R. 22 E. & Daggett & Prionocyclus novimexicanus (Marcou), Inoceramus perplexus Whitfield \\
\hline 3-31 & 11665 & SE/4 sec. 11, T. 10 N., R. $101 \mathrm{~W}$. & Moffat & Neogastroplites americanus (Reeside and Cobban, 1960) \\
\hline 211-32 & D9280 & NW/4 sec. 30, T. 10 N., R. $100 \mathrm{~W}$. & Moffat & Prionocyclus hyatti (Stanton), Inoceramus n. sp. \\
\hline 21-33 & D9281 & NW/4 sec. $30, T .10$ N., R. 100 W. & Moffat & Inoceramus aff. I. cuvieri Sowerby \\
\hline 24-34 & $\mathrm{D} 9282$ & NW/4 sec. 30, T. 10 N., R. 100 W. & Moffat & Scaphites whitfieldi Cobban, Inoceramus perplexus Whitfield \\
\hline 2-35 & 988 & $\mathrm{E} / 2$ sec. 10, T. 1 S., R. $5 \mathrm{E}$. & Summit & Neogastroplites cornutus (Reeside and Cobban, 1960) \\
\hline $18-36$ & & Coalville area & Summit & $\begin{array}{l}\text { Mytiloides mytiloides" (Cobban and Reeside, 1952), Mytiloides opalensis } \\
\text { Bose (Ryer, 1976) }\end{array}$ \\
\hline $\begin{array}{r}19-37 \\
19-38\end{array}$ & D11043 & $\begin{array}{l}\mathrm{SE} / 4 \text { sec. } 5, \mathrm{~T} .1 \mathrm{~S} ., \mathrm{R} .5 \mathrm{E} . \\
\text { Coalville area }\end{array}$ & $\begin{array}{l}\text { Summit } \\
\text { Summit }\end{array}$ & $\begin{array}{l}\text { Collignoniceras woollgari (Mantell), Mytiloides sp. } \\
\text { Collignoniceras woollgari (Cobban and Reeside, 1952) }\end{array}$ \\
\hline $27-39$ & & Coalville area & Summit & $\begin{array}{l}\text { Inoceramus cf. I. deformis, Lopha sannionis, Baculites mariasensis, Cardium } \\
\text { curtum (Cobban and Reeside, 1952), Inoceramus deformis Meek (Ryer, } \\
\text { 1976) }\end{array}$ \\
\hline $27-40$ & & Coalville area & Summit & $\begin{array}{l}\text { Inoceramus deformis Meek, Baculites cf. B. mariasensis Cobban, } \\
\text { Inoceramus koeneni Muller, Inoceramus inconstans Woods, Cardium curtum } \\
\text { Meek and Hayden (Ryer, 1976) }\end{array}$ \\
\hline $21-41$ & D12012-15 & $\mathrm{E} / 2$ sec. 2. T. 15 S., R. $11 \mathrm{E}$. & & Inoceramus howelli White, Inoceramus flaccidus White \\
\hline $23-42$ & $\begin{array}{l}\text { D12048 } \\
\text { D12777 } \\
\end{array}$ & SW/4 sec. 15, T. 15 S., R. $11 \mathrm{E}$. & Carbon & $\begin{array}{l}\text { Scaphiles warreni Meek and Hayden, Prionocyclus wyomingensis } \\
\text { Meek, Inoceramus dimidius White, Lopha lugubris (Conrad) }\end{array}$ \\
\hline
\end{tabular}




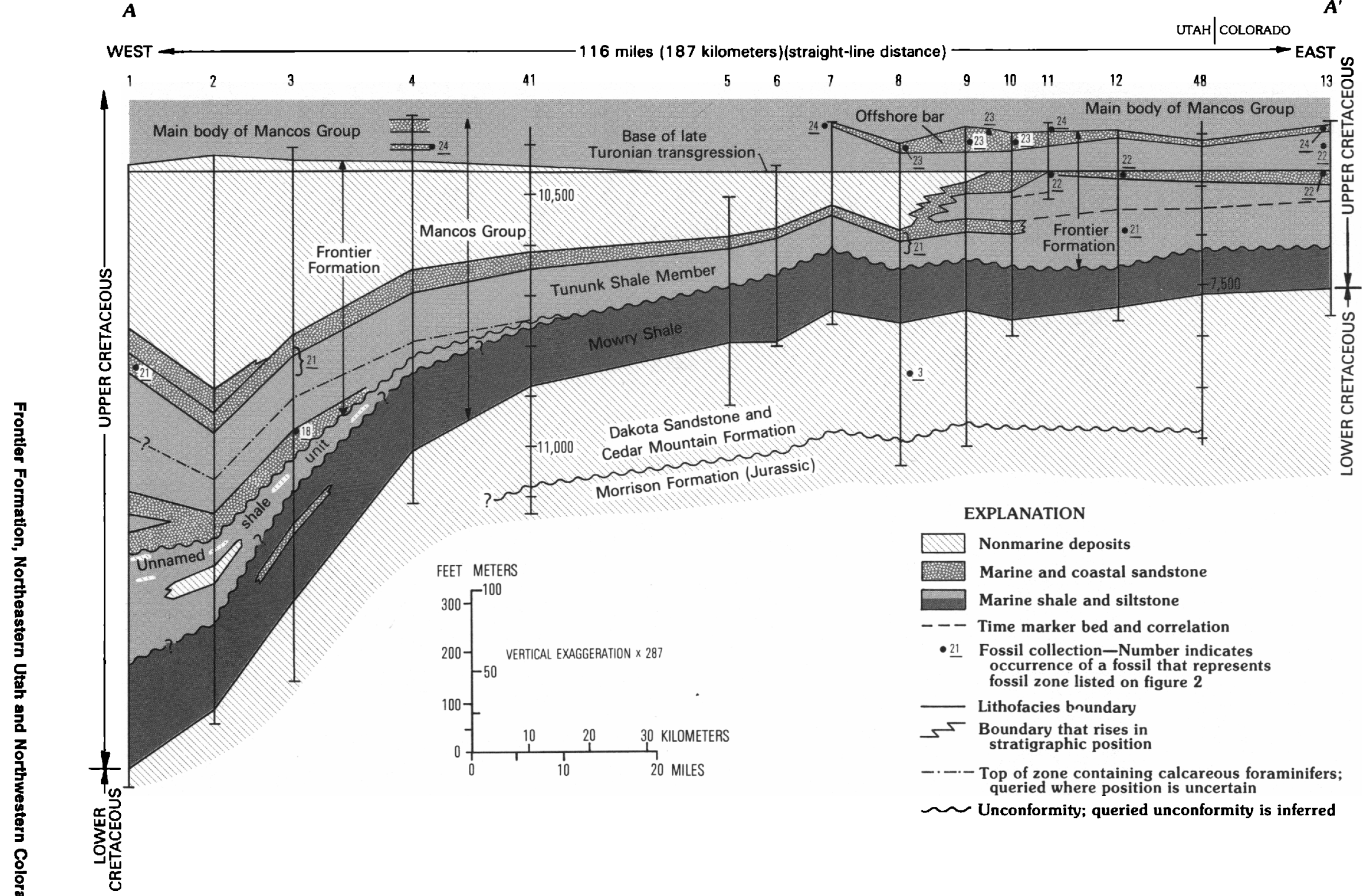

Figure 3. Stratigraphic correlation section on south side of Uinta Mountains. Line of section is shown in figure 1; control points are listed in table 1. Well depths indicated are in feet below Kelly bushing. 


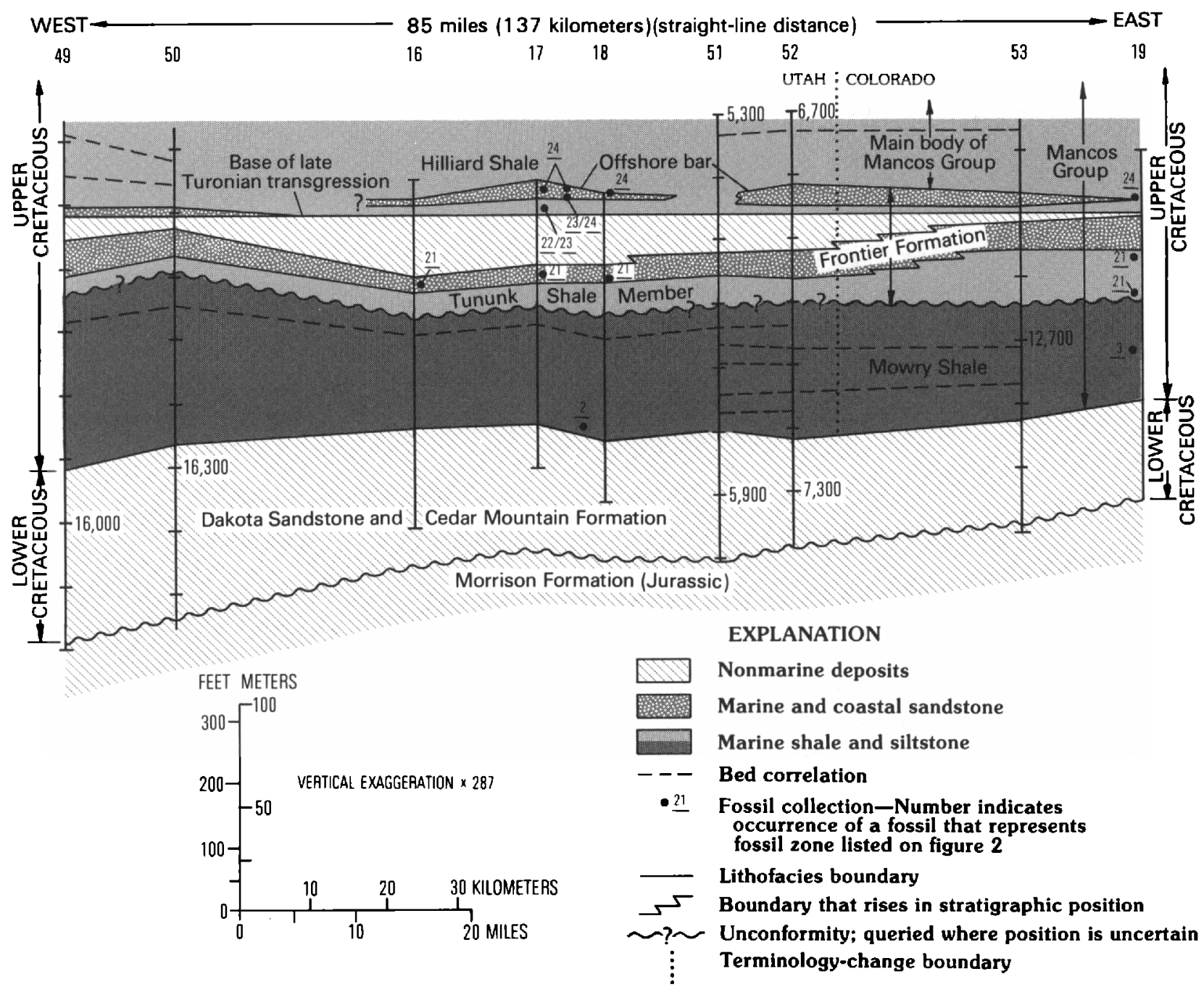

Figure 4. Stratigraphic correlation section on north side of Uinta Mountains. Line of section is shown in figure 1; control points are listed in table 1. Well depths indicated are in feet below Kelly bushing.

underlying Cedar Mountain Formation. These units are generally combined in discussions of mapped units (Kinney, 1955; Hansen, 1965), presumably because of the scale in mapping and (or) difficulties in mapping a contact. Indeed, both Kinney and Hansen assigned the combined sequence to the Dakota Sandstone. In mapping the Vernal $1^{\circ} \times 2^{\circ}$ quadrangle, Rowley and others (1985) recognized a differentiation of the Cedar Mountain and Dakota in parts of the area. Whether or not these units are separable, or even if the Cedar Mountain is present in the study area, is beyond the scope of our investigation, but we do show the combined unit in measured outcrop sections for the locations where they are exposed. In addition, some of the drill-hole logs of these rocks are shown in the stratigraphic correlation sections. The combined thickness of the two formations is $150-250 \mathrm{ft}(46-76 \mathrm{~m})$. The formations generally consist of resistant sandstone and conglomeratic sandstone units as thick as 50 feet $(15 \mathrm{~m})$, separated by nonresistant, commonly covered units of shale as thick as $90 \mathrm{ft}(27 \mathrm{~m})$. The sandstones are light gray and fine to medium grained, with lesser amounts of coarse and very fine grains. Scattered chert pebbles are locally common in some units; pebbles are sufficiently abundant in some beds to form conglomerate. In many but not all beds, the grain size decreases upward. Many of the beds, however, are composited depositional units and the grain size distribution is irregular. Sorting is good to moderate, and in some of the sandstone beds pores are filled with clay. Trough cross bedding is common; paleocurrent directions are indicated in plate 1 (sections $A-A^{\prime}, D-D^{\prime}$ ).

The shales are bentonitic and are light greenish gray in the lower part of the sequence and generally medium to dark gray in the upper part. This difference in color is commonly the basis for differentiating the Cedar Mountain Formation below from the Dakota Sandstone 
above; however, because some of the shale in what was considered as Dakota is greenish gray, the two formations were not separated.

The basal contact of the Cedar Mountain Formation is the base of the lowest sandstone bed overlying a thick shale unit in the upper part of the Morrison. This shale is variegated, including red.

Both the Cedar Mountain Formation and Dakota Sandstone were deposited in nonmarine environments except in some places, the upper few feet of the Dakota contains a thin sandstone that was deposited in a transgressive marine environment.

\section{Mowry Shale}

The Mowry Shale of early Cenomanian age sharply but conformably overlies the Dakota Sandstone. The Mowry formerly was considered late Albian (Early Cretaceous) in age on the basis of Neogastroplites fauna; however, Cobban and Kennedy (1989) now consider that Neogastroplites americanus, which occurs in the middle of the Mowry Shale in the report area (plate $1, A-A^{\prime}$, $D-D^{\prime}$ ), and possibly $N$. comutus, which occurs in the lower part of the Mowry (plate 1, $D-D^{\prime}$ ), are probably early Cenomanian in age. In addition, Eicher (1965) reported calcareous planktonic foraminifers from the upper $26 \mathrm{ft}(8 \mathrm{~m})$ of the Mowry Shale along the Front Range in northern Colorado that also indicate a Cenomainan age for at least part of the Mowry. Hence, the Mowry Shale in this report is considered early Cenomanian in age. Regardless of where the Albian-Cenomanian boundary lies, the absolute age at the top of the Mowry is about $96 \mathrm{Ma}$ inasmuch as the radiometric ages assigned to the Mowry are from bentonite beds in the Mowry (Obradovich and Cobban, 1975).

The Mowry is widespread throughout the northern Rocky Mountains and was deposited during the first marine transgression of the Cretaceous seaway, which advanced from the north or northeast. In the study area, the Mowry ranges in thickness from about $285 \mathrm{ft}(87 \mathrm{~m})$ at Bridger Lake to $80-90 \mathrm{ft}(24-27 \mathrm{~m})$ near the UtahColorado State line southeast of Vernal (fig. 1). Farther south in the Uinta basin and along the Douglas Creek arch (fig. 1), it thins to zero by depositional thinning and by grading into the underlying Dakota Sandstone (Sharp, 1963; Hale and Van de Graaff, 1964) or into undifferentiated Dakota(?)-Cedar Mountain deposits (Molenaar, unpublished data).

The Mowry Shale consists of interbedded, platy to fissile, hard, dark-gray, siliceous shale and bentonite. Fossil fish scales and fish bone fragments characterize the Mowry. Some parts of the Mowry are more siliceous than others as indicated by resistivity logs of drill holes and the variable resistance to erosion of outcrops. On the south side of the Uinta Mountains from Vernal eastward (fig. 1), the upper part of the Mowry is more siliceous than the lower part. On the north side, however, the top of the Mowry is softer (less resistant to erosion) and is about 30-35 $\mathrm{ft}(9-11 \mathrm{~m})$ above a more resistant unit of the formation. The Mowry weathers to small, brittle, silver-gray chips of shale that strongly contrast with overlying and underlying shales (fig. 5). Even in areas of rubble or mostly covered outcrops, the contacts can be located. On resistivity logs from drill holes, the Mowry is distinguished from shales of the overlying Frontier Formation by the greater resistivity of the Mowry. In some areas on the north side of the Uinta Mountains, where the uppermost part of the Mowry is less resistive and less siliceous, the placement of the upper contact on drill-hole logs is less certain.

At Farm Creek (control point 3, plate 1, section $A-A^{\prime}$ ) on the south side of the Uinta Mountains, a poorly exposed sandstone unit occurs near the middle of Mowry Shale. This anomalous sandstone, about $25 \mathrm{ft}$ thick, is poorly consolidated, well sorted, and upper very fine grained in the lower part grading upward to lower fine grained. We interpret this unit to be an offshore bar, but did not trace it or recognize it elsewhere.

\section{Unnamed Shale Unit}

An unnamed shale unit separates the Mowry Shale from the overlying Frontier Formation in the western outcrops on the south side of the Uinta Mountains (fig. 3; plate 1 , section $\left.A-A^{\prime}\right)$. This unit ranges in thickness from about $200 \mathrm{ft}(60 \mathrm{~m})$ in the Currant Creek and Red Creek areas (control points 1,2 ) to a pinchout edge between Pigeon Water Creek (control point 4), and Grouse Creek (control point 5). It is a soft-weathering unit and

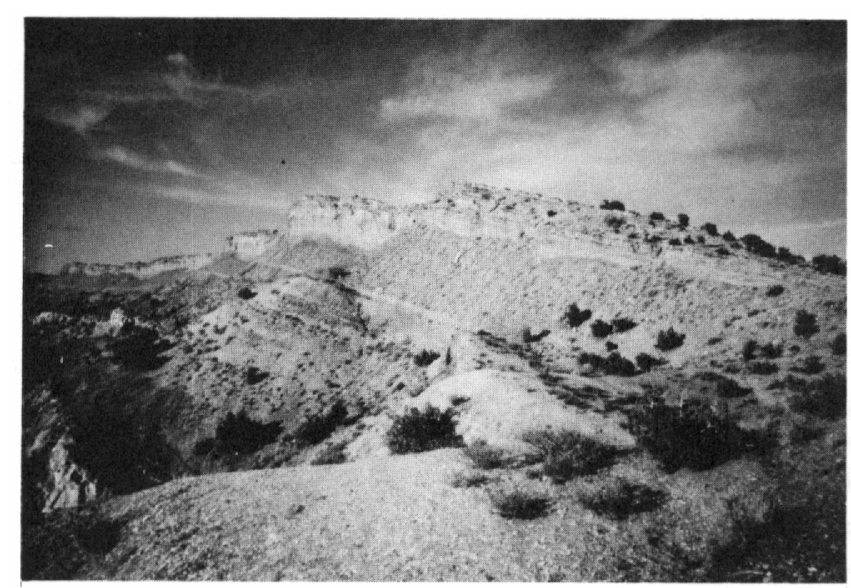

Figure 5. Lower part of Frontier Formation unconformably overlying Mowry Shale. Contact between light-grayweathering Mowry Shale and Tununk Shale Member is at top of light-colored bed in center and foreground of photograph. Coastal sandstone and nonmarine beds cap the ridge. Along east side of Steinaker Reservoir (NE1/4 sec. 35, T. 3 S., R. 21 E.). 
consequently is covered in most areas. The best exposures are at the Farm Creek section (control point 3 ), and even there the unit is largely covered. The unit's presence can usually be determined by shallow digging. The unit consists of moderately soft, dark-gray, nonfissile shale or silty claystone. Thin beds of carbonaceous or lignitic shale occur in the upper part. A 37-ft-thick (11 m) unit of fine- to medium-grained, fluvial conglomeratic sandstone and carbonaceous shale occurs in the middle of the unnamed shale unit in the Red Creek area (control point 2).

The unnamed shale unit contrasts sharply with the more resistant siliceous Mowry Shale. Even where the units are mostly covered, the silver-gray chips of Mowry in the float readily mark the contact. Based on the abrupt change in shale type, the contact is inferred to be unconformable. This inferred unconformity is shown as queried on figure 3.

Microfossil analyses of several shale samples indicate the presence of the arenaceous foraminifers, Miliammina manitobensis, Miliammina ischnia, Haplophragmoides hendersonense, and Verneuilina canadensis. These faunas were correlated by the late L.D. Holcomb of Shell Oil Company with the pre-Melloriolum zone of Eicher (1965), which is in the lower part of the Cenomanian Graneros Shale. The association of the shale containing foraminifers with the paludal carbonaceous shale and fluvial sandstone indicates that the shale unit is marginal marine in origin. Possibly the nonmarine or more restricted facies in the upper part of the unit may reflect a low stand of sea level in early Cenomanian time at about 95.3 $\mathrm{Ma}$ (Haq and others, 1987).

\section{Frontier Formation}

The Frontier Formation of Turonian (Late Cretaceous) age unconformably overlies the Mowry Shale in most of the study area and the unnamed shale unit on the west. The Frontier ranges in thickness from about $760 \mathrm{ft}(232 \mathrm{~m})$ at Currant Creek and Red Creek (control points 1, 2, plate 1, section $A-A^{\prime}$ ), the westernmost exposures on the south side of the Uinta Mountains, to $140 \mathrm{ft}(43 \mathrm{~m})$ at Vermillion Creek (control point 19 , plate 1 , section $D-D^{\prime}$ ) in northwesternmost Colorado (fig. 1). For discussion purposes, the Frontier is divided into six genetic lithofacies, some of which are areally restricted. In ascending order, these facies are: (1) a basal transgressive marine sandstone on the west, (2) an overlying marine shale unit that onlaps the Mowry Shale to the east and is here referred to as the Tununk Shale Member of the Frontier, (3) a prograding shallowmarine coastal sandstone, (4) a wedge of nonmarine sandstone, shale, and coal, (5) an upper transgressive coastal sandstone on the west, and (6) an offshore bar sandstone on the east (fig. 6). Facies 3 and 4 have been referred to as the Vernal delta by Hale and Van de Graaff (1964), and Ryer and Lovekin (1986). Plate 1 (sections $A-A^{\prime}, D-D^{\prime}$ ) shows the facies correlations and biostratigraphic control on both sides of the Uinta Mountains using detailed outcrop sections and available drill-hole logs for areas devoid of outcrops. Figures 3 and 4 show the same correlations with fewer details to show the overall relations.

\section{Basal Sandstone}

A basal sandstone of the Frontier on the south side of the western part of the Uinta Mountains is the oldest part of the Frontier in the study area and is interpreted as a transgressive marine sandstone (plate 1 , section $A-A^{\prime}$ ). In the Red Creek and Farm Creek areas, the sandstone unit is about $50 \mathrm{ft}(15 \mathrm{~m})$ thick, is fine to very fine grained, and contains common to abundant oysters and a few other bivalves. Its contact with the underlying unnamed shale unit is sharp; in some places the sandstone fills scours in the underlying shale. The contact is interpreted to be unconformable. The inoceramid Mytiloides mytiloides from the upper part of the sandstone indicates an early Turonian age for this unit. The sandstone thickens to the west and thins to zero, probably by depositional onlap, to the east between control points 3 and 4 (plate 1, section $A-A^{\prime}$ ).

\section{Tununk Shale Member}

A marine shale unit that sharply but conformably overlies the basal sandstone in the western part of the south flank of the Uinta Mountains is the basal unit of the Frontier in most other parts of the study area, where it unconformably overlies the Mowry Shale (figs. 3, 4).

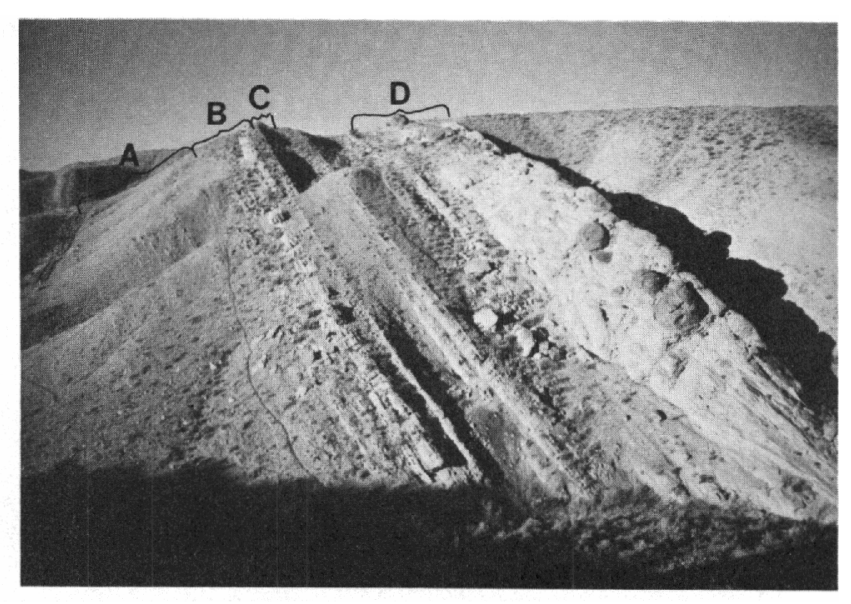

Figure 6. Frontier Formation exposed along Jensen Wash (fig. 1, control point 9). A, Tununk Shale Member; B, coastal sandstone; C, nonmarine deposits; D, offshore-bar sandstone (note large concretions). 
This shale unit ranges in thickness from less than $50 \mathrm{ft}$ $(15 \mathrm{~m})$ to more than $150 \mathrm{ft}(46 \mathrm{~m})$ and correlates with, and is continuous with, the Tununk Member of the Mancos Shale along Castle Valley and the Wasatch Plateau southwest of the Uinta basin (fig. 1). In the study area, we propose calling this shale unit the Tununk Shale Member of the Frontier Formation of the Mancos Group to emphasize its stratigraphic relation with the same named member of the Mancos Shale on the south side of the Uinta basin. The Tununk consists of dark-gray silty shale and siltstone that weathers light brown, in strong contrast to the underlying silver-gray-weathering Mowry Shale (fig. 5). Where it overlies the Mowry, the basal contact is sharp, and the lack of a paleosol or basal lag marking the unconformity is thought to be due to the unconformity being developed in a submarine environment on an offshore shoal. The uppermost part of the Tununk Member grades into the overlying regressive shallow-marine coastal sandstone.

Microfaunal determinations by Shell Oil Company indicate that the lower half of the Tununk Member in the Farm Creek and Red Creek areas (control points 2, 3, plate 1, section $A-A^{\prime}$ ) and the basal part of the Tununk at Pigeon Water Creek (control point 4) contain the calcareous foraminifers, Globigerina, Gumbelina, Dentalina, Gyroidina, and Marginulina. These faunas correlate with the Greenhorn Limestone Member of the Mancos Shale, which in this part of the Western Interior seaway is mostly early Turonian in age. The middle Turonian fossil Prionocyclus hyatti occurs in the upper part of the Tununk Member in that area. Fossils of the early middle Turonian zones of Collignoniceras woollgari and Prionocyclus percarinatus have not been reported, but we believe this zone is represented in the western part of the area. Although outcrops of the shale unit are subdued, there is no physical evidence of an unconformity within the shale unit. A dot-dashed line on plate 1 (section $\left.A-A^{\prime}\right)$ and on figure 3 marks the top of the calcareous Foraminifera zone.

To the east along the south side of the Uinta Mountains, the Tununk Member overlaps the basal sandstone and the unnamed Cenomanian shale unit and onlaps onto the Mowry Shale. Where it rests directly on the Mowry, the Tununk Member is late middle Turonian in age (zone of Prionocyclus hyatti). The lower and lower middle Turonian parts of the member probably have lapped out. East of the stratigraphic rise of the overlying coastal sandstone in the eastern part of the area, the upper part of the Tununk probably ranges into the late Turonian (zone of Prionocyclus macombi) (plate 1, section $A-A^{\prime}$ ).

\section{Regressive Coastal Sandstone}

The regressive coastal sandstone separates offshore marine shale below (and seaward) from overlying (and landward) nonmarine deposits. It gradationally overlies the Tununk Shale Member; the gradation from silty shale to sandstone commonly occurs over a 10- to 20-ft-thick (3-6 m) interval, but in some areas the interval is much thicker. The sandstone unit ranges in thickness from about $20 \mathrm{ft}(6 \mathrm{~m})$ to as much as $90 \mathrm{ft}$ $(27 \mathrm{~m})$ and consists mostly of well-sorted, upwardcoarsening, very fine to lower fine grained sand. In the Currant Creek and Red Creek areas on the west (plate 1, section $A-A^{\prime}$ ), thick, crossbedded, upward-fining sequences in the upper half of the total unit are interpreted as estuarine channel sandstones. Ophiomorpha burrows and scattered fragments of Inoceramus and oyster shells indicate a marine influence or origin. Similarly, at Donkey Flat (control point 14, plate 1, section $C-C^{\prime}$ ), an upward-fining sandstone unit that sharply overlies a normal upward-coarsening regressive shoreface sandstone is interpreted as a tidal-channel or possibly estuarine-channel sandstone. This unit contains almost opposed crossbeds and large Ophiomorpha in the top few inches.

Over most of the area, the coastal sandstone is late middle Turonian in age (zone of Prionocyclus hyatti). East or southeast of the abrupt stratigraphic rise between control points 8 and 9 (plate 1, section $A-A^{\prime}$; fig. 3 ), a few collections indicate an early late Turonian age (zone of Prionocyclus macombi). This age dates the relative sealevel rise as occurring between these two zones. The ramifications of this relative sea-level rise as it relates to other areas is discussed later.

The coastal sandstone deposited prior to the relative rise in sea level grades eastward into an offshore shelf siltstone or very fine grained sandstone, as indicated by resistivity logs of drill holes (plate 1 , section $B-B^{\prime}$ ). This offshore equivalent of the unit is not obvious in the outcrop sections because it is generally covered or poorly exposed.

The seaward extent of the upper or last coastal sandstone unit extends far beyond the study area as a thin offshore shelf sandstone (see control point 13 on plate 1, section $A-A^{\prime}$ ). This sandstone indicates a widespread uniformly shallow sea during deposition of this part of the Frontier.

\section{Nonmarine Deposits}

Nonmarine deposits overlie and in places fill scours at the top of the coastal sandstone unit. This nonmarine unit ranges in thickness from about $430 \mathrm{ft}(130 \mathrm{~m})$ at control point 2 near Red Creek to a pinchout edge between control points 9 and 10 east of Vernal (fig. 3). On the north side of the Uinta Mountains, it is thickest near control point 16 in the Manila area, where only about $100 \mathrm{ft}(30 \mathrm{~m})$ is present (fig. 4). The nonmarine unit represents subaerial deposition on a delta plain or coastal plain and consists of paludal and interfluvial 
carbonaceous shale, fluvial and distributary channelfilling sandstone, and a small amount of coal. The channel-filling sandstones are as thick as $50 \mathrm{ft}(15 \mathrm{~m})$ and consist generally of upward-fining sequences of fine- to medium-grained, crossbedded sandstone. Clay galls are common, but the only hard pebbles noted are in a conglomeratic bed near Flaming Gorge Reservoir east of Manila. The channel-filling sandstones cut into the underlying coastal sandstones in some places, especially immediately west of the area of the abrupt stratigraphic rise of the coastal sandstone in the Vernal area (plate 1, section $A-A^{\prime}$; fig. 3). Maione (1971) interpreted many of the channel sandstones in the Steinaker Reservoir area north of Vernal as a fluvial-estuarine sandstone facies.

Paleocurrent directions indicated by crossbeds in the fluvial sandstones suggest that the streams or rivers flowed generally southeast on the south side of the Uinta Mountains (plate 1 , section $A-A^{\prime}$ ) and northeast on the north side (plate 1 , section $D-D^{\prime}$ ). These directions fit the inferred trend of the paleoshoreline (to be discussed later).

Coal is not abundant, but thin beds are scattered throughout the nonmarine unit. Thicker coal beds occur in the upper part, generally the part with fewer channelfilling sandstone beds. Coal was mined or prospected in many areas between Red Creek on the west and Brush Creek east and northeast of Vernal along the south flank of the Uinta Mountains (fig. 1) (Doelling and Graham, 1972). Hansen (1965) reported a coal bed about $2 \mathrm{ft}(50$ $\mathrm{cm}$ ) thick near control point 17 on the north flank of the mountains.

The westward thickening of the nonmarine unit on the south side of the Uinta Mountains (plate 1, section $A-A^{\prime}$; fig. 3) probably is due to either or both increased tectonic downwarping toward the foredeep to the west and (or) sediment loading. The thin section at Coal Mine Basin (control point 7) is interpreted to be caused, at least in part, by the greater compaction of a more coaly sequence during deposition of the overlying marine shale, which is correspondingly thicker than at adjacent control points. Another contributing factor to this thickness anomaly is that, prior to the marine transgression, this area may have been topographically lower, possibly a lake with a bottom below sea level.

On the north side of the Uinta Mountains, the nonmarine unit as well as the total Frontier thins toward the Bridger Lake area (plate 1, section $D-D^{\prime}$; fig. 4). This thinning is possibly due to the affects of the Moxa arch, which trends into this area from the north (Lickus and Law, 1988). There are no indications that the Moxa arch affected deposition of the Frontier or Mowry (thinning of the section) on the south flank of the Uinta Mountains (plate 1, section $A-A^{\prime}$ ).

\section{Transgressive Coastal Sandstone}

A transgressive coastal sandstone unit, which conformably overlies the nonmarine rocks, crops out along the south flank of the western part of the Uinta Mountains (control points 1-4, plate 1, section $A-A^{\prime}$ ). Except for a very thin ( $<5 \mathrm{ft}$ ) sandy zone in some areas, the unit is not present in outcrops along the flanks of the eastern part of the Uinta Mountains. Based on interpretations of well logs, a transgressive sandstone is present in the Bridger Lake area on the north side of the Uintas (control points 49,50 , plate 1 , section $D-D^{\prime}$ ). The transgressive coastal sandstone abruptly overlies nonmarine deposits; a coal bed, which has been mined in some areas, commonly underlies or is a short distance beneath the sandstone unit. The upper contact of the sandstone is usually concealed but is presumed to be at the base of the main (shale) body of the Mancos Group. At Pigeon Water Creek (control point 4, plate 1, section $\left.A-A^{\prime}\right)$, however, the transgressive sandstone is overlain by about $80 \mathrm{ft}(24 \mathrm{~m})$ of mostly offshore sandstone. The transgressive coastal sandstone unit is about $20-25 \mathrm{ft}$ $(6-8 \mathrm{~m})$ thick and consists of very well sorted, white to light-gray, massive to crossbedded, fine-grained sandstone. Burrows, pelecypod molds, and shale chips are common in the sandstone; generally the sandstone is very clean and porous.

\section{Offshore-Bar Sandstone}

Sandstone deposited as an offshore bar is present on both flanks of the eastern part of the Uinta Mountains (plate 1 , sections $A-A^{\prime}, D-D^{\prime}$ ). This sandstone unit is separated from the main regressive part of the Frontier Formation by a 15- to 90 -ft-thick (5-27 m) tongue of transgressive marine shale. The offshore-bar sandstone is gradational with the underlying shale and is sharply overlain by the main body of the Mancos Group. The sandstone ranges in thickness from $53 \mathrm{ft}(16 \mathrm{~m})$ northeast of Vernal (control point 9, plate 1, section $A-A^{\prime}$ and fig. 6) to a pinchout within the Mancos to the west near Coal Mine Basin northwest of Vernal (control point 7, plate 1 , section $A-A^{\prime}$ ). Seaward to the east or southeast, the sandstone extends beyond the study area as a ripplebedded, offshore-shelf sandstone about $10 \mathrm{ft}(3 \mathrm{~m})$ thick. Plate 1 (sections $A-A^{\prime}, C-C^{\prime}, D-D^{\prime}$ ) shows the thickness variations and stratigraphic relations.

In the study area where the offshore-bar sandstone is well developed, it consists of buff-colored, very fine grained sandstone that coarsens very slightly upward. The sandstone is generally thoroughly bioturbated, and large concretions are common in the upper half (fig. 6).

Whether an offshore bar extends or builds up in the western part of the area is not known because the section above the main part of the Frontier is mostly covered. At Pigeon Water Creek (control point 4, plate 1, section 
$A-A^{\prime}$ ) several marine sandstone beds occur within an 80 -ft-thick $(24 \mathrm{~m})$ interval above the main part of the Frontier. It cannot be demonstrated if these are isolated bars or if they merge with coastal sandstones to the west.

\section{Extent of Subaerial-Plain Deposits (shoreline trend)}

The seaward extent of subaerial-plain deposits (nonmarine facies), unless subsequently eroded, defines the trend of the shoreline at the time of maximum regression of the Frontier Formation (fig. 1). Along the south flank of the Uinta Mountains, the easternmost outcrop or seaward extent of subaerial-plain deposits is in the SW1/4SW1/4 of sec. 28, T. 4 S., R. $23 \mathrm{E}$., about $1 \mathrm{mi}$ ( $2 \mathrm{~km}$ ) west of control point 10 (plate 1 , section $A-A^{\prime}$ ). At control point 15 (plate 1 , section $C-C^{\prime}$ ) on the north side of Split Mountain, the nonmarine deposits are very thin; consequently the eastern limit is a short distance to the east. Similarly, at Vermillion Creek (control point 19, plate 1 , section $D-D^{\prime}$ ) on the north side of the Uinta Mountains, the nonmarine deposits are only about $4 \mathrm{ft}$ $(1 \mathrm{~m})$ thick; therefore, the maximum seaward extent is a short distance to the east. A line connecting these three points trends approximately N. $60^{\circ} \mathrm{E}$.

To the southwest across the Uinta basin, the seaward extent of nonmarine rocks is west of Farnham dome (control point 21, fig. 1). Facies interpretations of drill-hole logs by Hale (1972) and Ryer and McPhillips (1983) indicate the position of the seaward extent to be about $10 \mathrm{mi}(16 \mathrm{~km})$ northwest of Farnham dome.

In Wyoming, north of the Uinta Mountains, control is limited to scattered drill holes. Because the wells are deep and the nonmarine section is relatively thin, it is difficult to define the limits of nonmarine rocks in that area, although Hale and Van de Graaff (1964) show the shoreline trending west-northwest. The thinness of nonmarine deposits in wells and outcrops along the north flank of the Uinta Mountains and the predominant northeast-trending current directions indicated by crossbeds in nonmarine channel sandstones (plate 1, section $\left.D-D^{\prime}\right)$ supports the interpretation of a northwest shoreline trend in that area.

\section{Correlations with Adjacent Areas}

Correlations of the Frontier Formation northward into Wyoming from northwesternmost Colorado and northeasternmost Utah are shown in Merewether (1983) and Merewether and others (1984). These are mostly subsurface correlations; the nearest outcrops, other than those in the thrust belt of southwestern Wyoming, are in south-central Wyoming near Sage Creek, $90 \mathrm{mi}(145 \mathrm{~km})$ east-northeast of the juncture of Utah, Colorado, and
Wyoming, or on the east flank of the Wind River Mountains, about $120 \mathrm{mi}(190 \mathrm{~km})$ north of the juncture. Because the nonmarine part of the Frontier is thin, if present, in the subsurface north of the Uinta Mountains, it is difficult or impossible to separate the nonmarine and marine facies on well logs. Because of the uncertainty in separating marine and nonmarine rocks, which we think is important in correlating and mapping facies, we do not include a figure showing correlations northward from the north flank of the Uinta Mountains. (Refer to Merewether (1983) and Merewether and others (1984) for these correlations.) It is interesting to note that the Belle Fourche Member of the Frontier, a dominantly marine shale unit of Cenomanian age, is present a short distance north of the eastern part of the Uinta Mountains, preserved under the unconformity that separates the Frontier and Mowry Shale in the study area (Merewether, 1983, fig. 8). This shale unit may have been coextensive with the unnamed Cenomanian shale unit that overlies the Mowry Shale along the southwestern side of the Uinta Mountains (fig. 1; plate 1, section $A-A^{\prime}$ ).

To the west and northwest of the study area, the Frontier Formation is exposed on allochthonous thrust sheets (fig. 1). In the Coalville area, the Frontier is about $7,800 \mathrm{ft}(2,377 \mathrm{~m})$ thick and includes strata both older and younger than those in the Frontier in the study area (Hale, 1962; Ryer, 1976). Figure 7 shows the correlation of the Frontier Formation and associated rocks between the Coalville area and Red Creek. This correlation is similar to that of Hale and Van de Graaff (1964). Included in this correlation is the Mancos Group and the total Mesaverde Formation (generalized) at Red Creek, which we measured. The main body of the Mancos is covered, but the calculated thickness is thought to be reasonable. Attitudes in the Frontier below the main body of the Mancos and in the overlying lower part of the Mesaverde are consistent; dips are about $45^{\circ}$ to the south. The Mesaverde is unconformably overlain by the uppermost Cretaceous-Paleocene Currant Creek Formation in that area. The homotaxial correlation of the Upton Sandstone Member of the Frontier Formation at Coalville with the Mesaverde at Red Creek is shown as very generalized. There could be minor marine shale

Figure 7 (following two pages). Correlation and comparison of Frontier Formation and total marine part of Cretaceous section between Coalville and Red Creek. Coalville section is modified from Hale (1962) and Ryer (1976). Line of section $E-E^{\prime}$ is shown in figure 1; not corrected for tectonic shortening between sections. Zone fossil data are shown in figure 2; fossil collection for Red Creek section (designated by $P$ ) is projected from Farm Creek and Currant Creek sections (control points 1 and 3 , fig. 3 , plate 1 , section $A-A^{\prime}$ ). Thick marine sandstones in Mesaverde Formation at Red Creok are stacked shoreface sequences. 


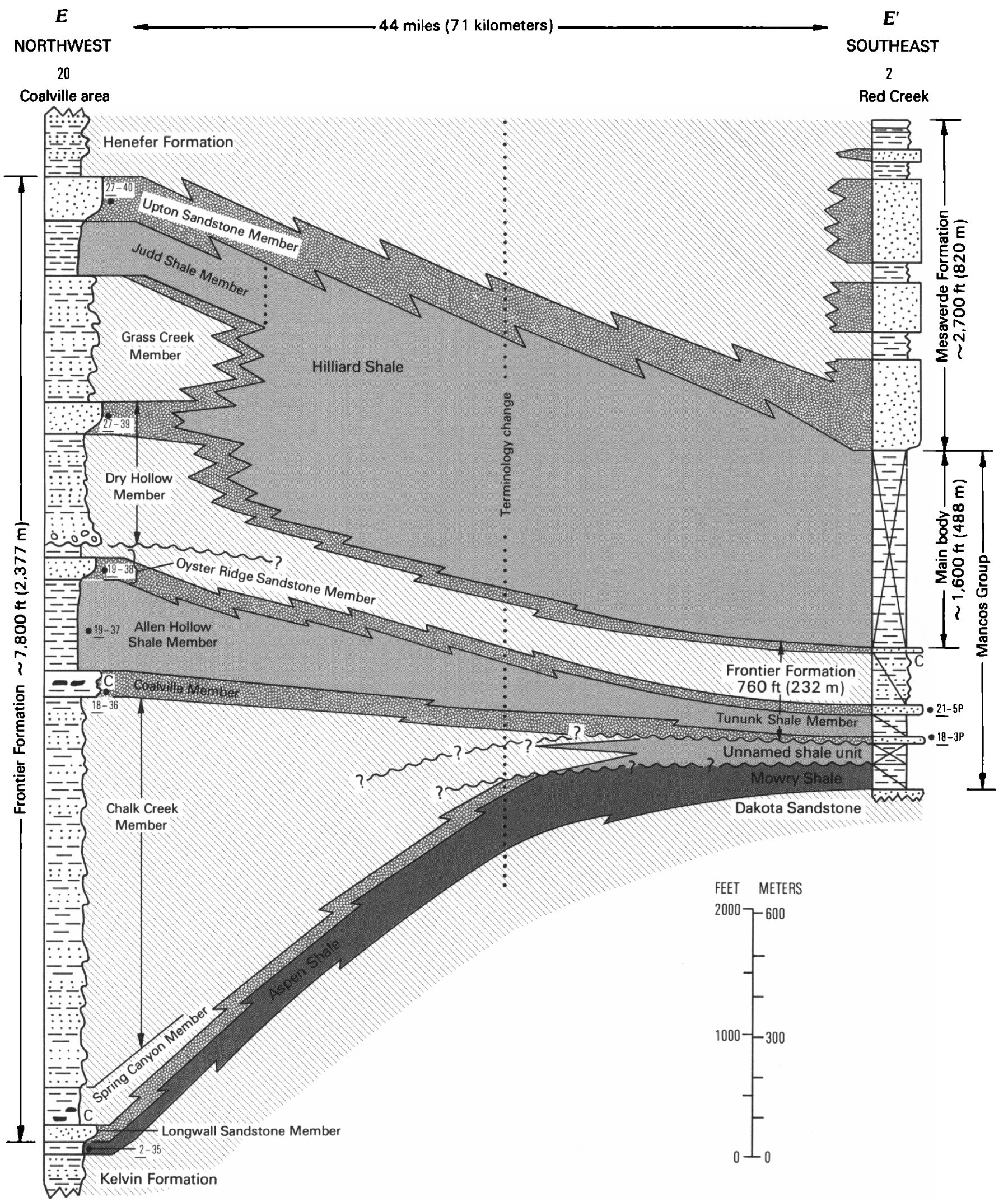




\section{EXPLANATION}

ACCESSORIES, MODIFIERS, AND SEDIMENTARY STRUCTURES

- Pebbles

Shale clasts or galls

() Concretions

- Carbonaceous

$\perp$ Calcareous

III Bentonite or bentonitic

( Crossbedded

$\theta$ Trace fossils (burrows)

\&ioturbated (churned)

万ा Root casts

F Fossiliferous

\section{LITHOFACIES PATTERNS}

Nonmarine deposits

Marine and coastal sandstones

Marine shale and siltstone

\section{MISCELLANEOUS}

21-41 - Zone fossil (underlined) and collection number (see fig. 2 and table 2)

Current direction trom crossbeds

\section{BOUNDARIES AND CORRELATIONS}

Lithofacies boundary

$\overrightarrow{ }$ Boundary that rises in stratigraphic position

Unconformity; queried where position is uncertain

- - Bed correlation

- - Top of zone containing calcareous foraminifers

\section{GENERAL LITHOLOGY SYMBOLS}

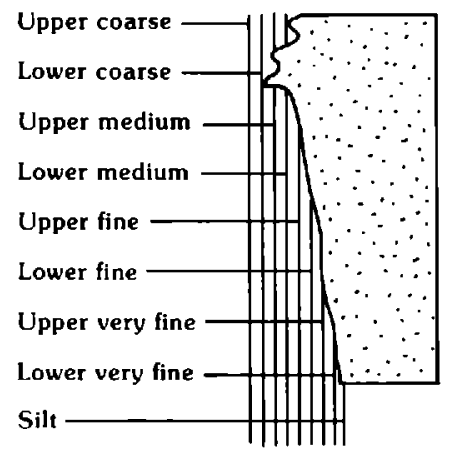

Sandstone. On sections where column excursion is to left, column width indicates visual estimate of medium grain size. Single row of dots extending outside of column represents a thin $(<1 \mathrm{ft})$ layer of coarser grains, the size of which is indicated. In essence, the left side of the column is a grain-size profile

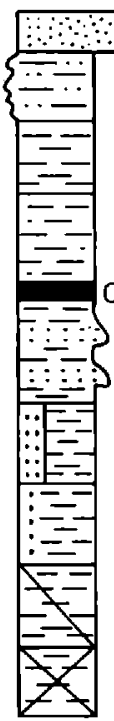

Sandstone. On section where column excursion is to right, no specific grain size is implied

Siltstone

Shale or claystone

Silty shale or mudstone

C Coal

Interbedded sandstone and shale or siltstone; generalized thick interval

Interbedded sandstone and shale or siltstone in which sandstone beds are too thin or too subdued to separate from sequence. Proportions of each are indicated

Interbedded sandstone and shale or siltstone in which sandstone proportions is less than 20 percent

Partially covered interval

Covered interval; lithology inferred if filled in 


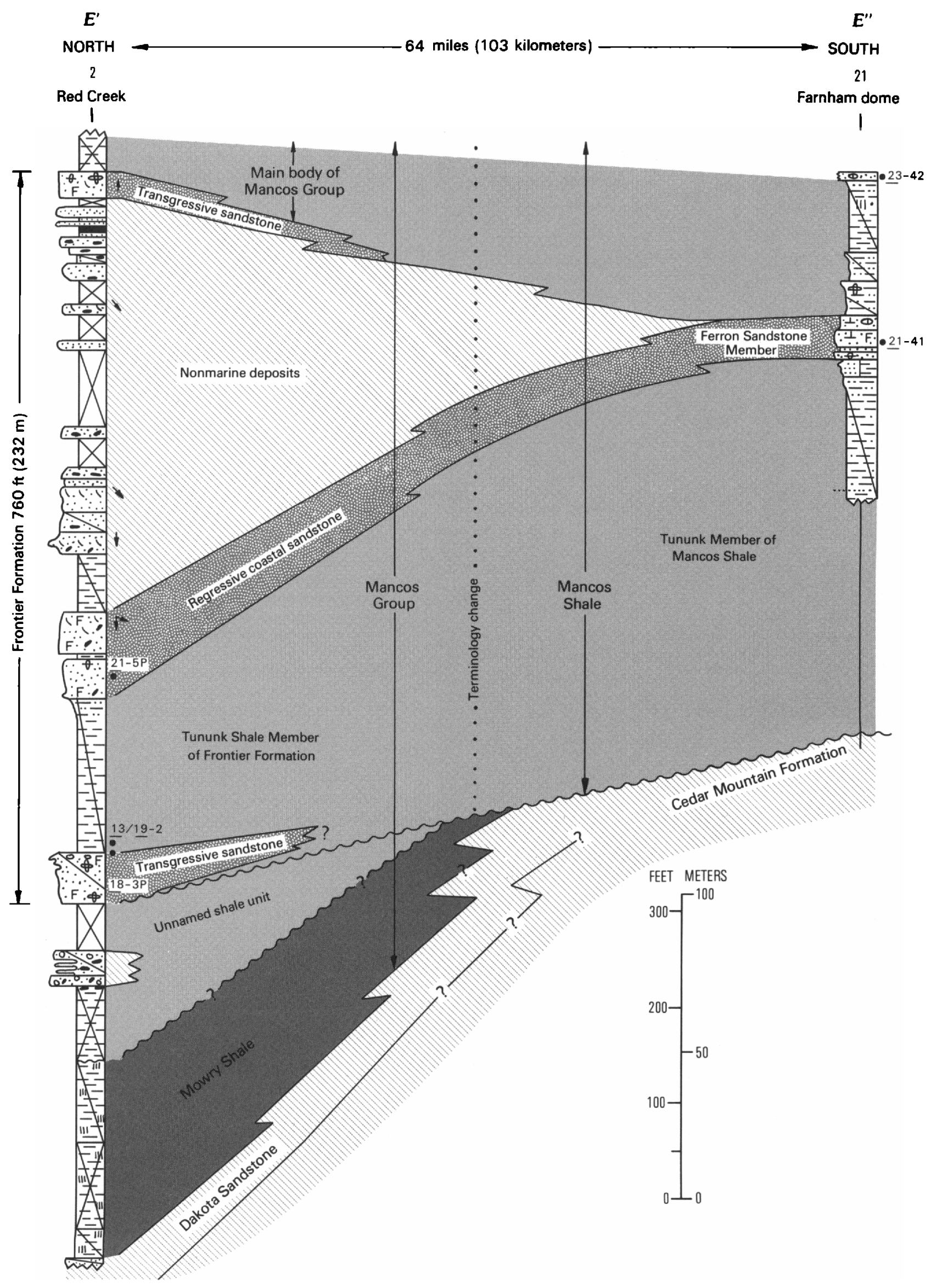

M16 Evolution of Sedimentary Basins -Ulnta and Plceance Basins 
tongues involved in the diachronous relation. The Upton Member is no younger than middle Coniacian and the Mesaverde at Red Creek is reported by Walton (1944) to contain fossils of Niobrara age. The Niobrara extends from the early Coniacian to the middle Campanian. Inoceramus cf. I. kleini Muller of possible late Coniacian age was collected by A.E. Merewether, W.A. Cobban, and Molenaar from a sandstone tongue about $200 \mathrm{ft}$ (60 $\mathrm{m})$ below the base of the Mesaverde in the Currant Creek area $9 \mathrm{mi}(14 \mathrm{~km})$ west-southwest of Red Creek. It seems likely that the Mesaverde at Red Creek is Santonian and possibly Campanian in age.

The unconformity at the top of the Mowry is interpreted to grade into a conformable sequence within the nonmarine Chalk Creek Member of the Frontier in the foredeep to the west. Similarly, the unnamed marginally marine shale unit, which contains some nonmarine beds on the western flank of the Uinta Mountains, is interpreted to grade into the upper part of the totally nonmarine Chalk Creek Member at Coalville. The lower middle Turonian Oyster Ridge Sandstone Member of the Frontier is interpreted as part of the same regression as the upper middle Turonian coastal sandstone in the Uinta Mountains area. The unconformity above the Oyster Ridge Sandstone Member is interpreted to be a basin-margin unconformity associated with orogenic activity farther west, and the unconformity grades into a conformable sequence to the east. As shown in figure 7, this gradation is inferred to be within the nonmarine section, which means the unconformity developed in middle to late Turonian time. Another interpretation is that the unconformity grades into a conformable sequence within the marine section to the east, thereby separating by truncation the upper marine sandstone at Red Creek from the Dry Hollow Member of the Frontier at Coalville. This interpretation would mean that the unconformity developed in latest Turonian-early Coniacian time. Control between the two areas is sparse or lacking.

The nearest outcrops of Frontier-equivalent rocks south of the Uinta Mountains area are at Farnham dome, southeast of Price on the south side of the Uinta basin (fig. 1). A sandstone unit in that area is known as the Ferron Sandstone Member of the Mancos Shale. Within the Uinta basin, there are few subsurface penetrations of the Frontier (or Ferron), except along the flanks of the

Figure 8 (facing page). Correlation and comparison of Frontier Formation at Red Creek and Ferron Sandstone Member of Mancos Shale at Farnham dome. Line of section $E^{\prime}-E^{\prime \prime}$ is shown in figure 1 . Zone fossil data are shown in figure 2; fossil collection for Red Creek section (designated by $P$ ) is projected from Farm Creek and Currant Creek sections (control points 1 and 3, fig. 3). For explanation of symbols and numbers see figure 7 .
Douglas Creek arch of the east side of the basin and along the south flank of the basin. One of the few penetrations in the central part of the basin was by the W.A. Moncrief Company Harsing No. 14-1 well in sec. 14, T. 5 S., R. 6 W., Uinta base meridian. This test penetrated the Frontier (or Ferron) at or below a depth of $18,000 \mathrm{ft}(5,900 \mathrm{~m})$. The geophysical logs of the well are inadequate for the identification or correlation of lithofacies. Figure 8 shows the correlation across the Uinta basin between Red Creek and Farnham dome. Again, this correlation is similar to that of Hale and Van de Graaff (1964).

\section{DISCUSSION}

\section{Unconformity at Base of Frontier Formation}

The unconformity at the contact of the Frontier Formation and the Mowry Shale represents a hiatus of as much as 6-7 m.y. (early Cenomanian to late middle Turonian.) Some authors (such as Weimer, 1962; Ryer and Lovekin, 1986) suggested that this unconformity is related to mid-Cretaceous growth of the Uinta Mountain uplift. Merewether and Cobban (1986), however, proposed, from biostratigraphic and subsurface studies, that the uplift associated with the unconformity was a broad, north-trending arch that extended into parts of Utah, Colorado, and Wyoming. Figure 9 shows their interpretation of the shape of the uplift during early middle Turonian time. Our work indicates that the unnamed Cenomanian shale unit and the lower Turonian part of the Frontier onlap the unconformity from west to east (plate 1 , section $A-A^{\prime}$ ), and that the alignment of the uplift may not coincide with or be parallel with the present-day axis of the Uinta Mountains. Surface and subsurface correlations on the south and east sides of the Uinta basin indicate that the unconformity at the top of the Mowry on the north side of the basin correlates with an unconformity separating the Cedar Mountain Formation and the Mancos Shale on the south side of the basin (Molenaar, unpublished data).

Although the age relations across the unconformity in the eastern and central parts of the study area are well documented, the amount of truncation, if any, and the time of uplift is speculative. For this discussion, we refer to this uplift as the Vernal high. The west-to-east thinning by possible truncation of the unnamed shale unit of Cenomanian age suggests that some of the unit may have been deposited over the Vernal high prior to relative uplift or shoaling and erosion of the high. Based on the eastward thinning of both the basal transgressive sandstone and the lower Turonian part of the Tununk 


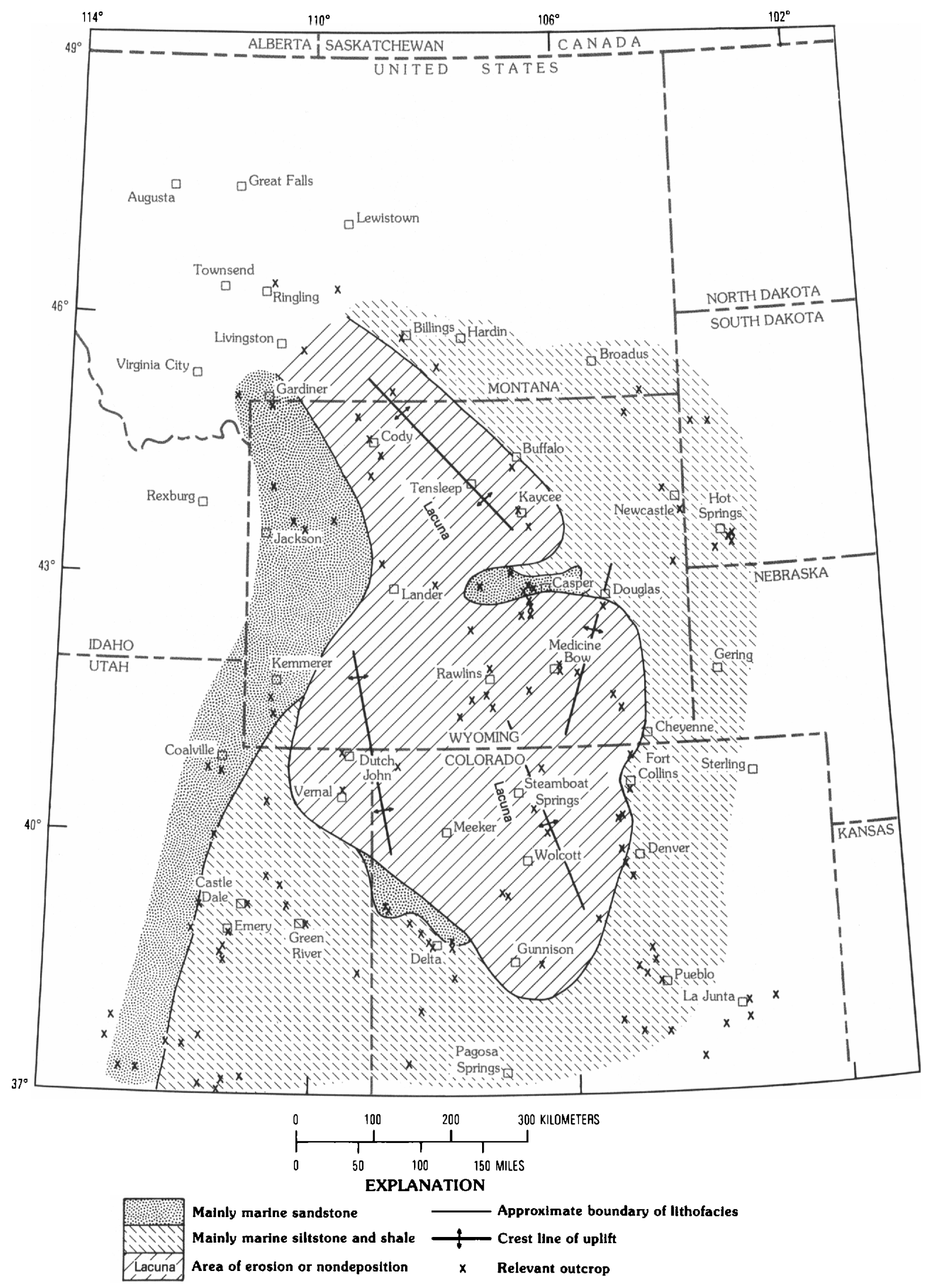


Shale Member (the part containing calcareous foraminifers as shown in plate 1 , section $A-A^{\prime}$; fig. 3 ), with no apparent unconformity within or above these rocks, we interpret that this part of the section onlaps the Vernal high. This interpretation is supported by well-log correlations along the east and southeast sides of the Uinta basin that show lower and lower middle Turonian rocks onlapping the Vernal high from the south (Molenaar, unpublished data).

Because there are no lag deposits or basal transgressive sandstones associated with the unconformity on the top of the Mowry Shale, it seems most likely that the unconformity developed in a submarine environment, probably as an offshore shoal far distant from a shoreline. Other authors also have suggested this mechanism (Weimer, 1962; Ryer and Lovekin, 1986). The unconformity probably developed because of tectonic uplift of the Vernal high peripheral to a developing foredeep to the west rather than eustatic lowering of sea level inasmuch as deposits associated with a late Cenomanian-early Turonian high stand of sea level (Haq and others, 1987) are missing by nondeposition or erosion on the high but are present landward to the west.

\section{Progradational Patterns and Relative Sea Level Rise}

From our investigations of the east-west-trending outcrop belts along the flanks of the Uinta Mountains, there is little evidence of stratigraphic rising of the prograding coastal sandstone, except just east of Steinaker Reservoir (between control points 8 and 9, plate 1 , section $A-A^{\prime}$; fig. 3 ) on the south side of the mountains and east of Antelope Flat (between control points 18 and 19 , plate 1 , section $D-D^{\prime} ;$ fig. 4 ) on the north side of the mountains. Because outcrops are discontinuous in most of the study area, the rising and (or) nonrising in stratigraphic position of the top of the coastal sandstone (which indicates approximate sea level at the time of deposition) are best indicated by the uniform thickness or thickness variations of the middle Turonian part of the underlying Tununk Shale Member as shown in plate 1 (sections $A-A^{\prime}, B-B^{\prime}$ ) and figure 3 . An abrupt change in the thickness of the overlying nonmarine strata also is an indication of a stratigraphic rise.

The rise in stratigraphic position of the top of the coastal sandstone unit (the marine-nonmarine boundary) is a measure of relative sea-level rise. The relative

Figure 9 (facing page). Distribution and lithofacies of early middle Turonian rocks (Collignoniceras woollgari fossil zone) in the central Rocky Mountains region. Modified from Merewether and Cobban (1986). sea-level or stratigraphic rises we discuss are due to either eustatic rises or basin subsidence or a combination of both. Because these two possible causes cannot be differentiated at the local level, we use the term "relative" to cover all cases. We interpret that relative sea level was fairly constant throughout the area while the coastal sandstone prograded eastward, prior to the time of the abrupt stratigraphic rise east of Steinaker Reservoir (control point 8, plate 1, section $A-A^{\prime}$ ).

Ryer and Lovekin (1986) attributed this regression to a eustatic lowering of sea level during the middle Turonian and an abundant supply of clastic sediment from the Sevier orogenic belt. The gradational contact of the regressive coastal sandstone with the underlying Tununk Shale Member suggests continuous deposition. If a eustatic drop did occur at that time, regional subsidence must have masked the effect of the fall in sea level, or after the sea-level drop water depths still must have been at or below wave base. Near the end of the uniform progradation period, however, prior to the rather abrupt stratigraphic rise, a time of downcutting apparently occurred during which the nonmarine channels cut down into the coastal sandstones. This was noted in several areas, such as at control points 5 and 7 (plate 1, section $A-A^{\prime}$ ). Furthermore, thin or incomplete coastal sandstone sequences, such as at control points 6 and 8 (Steinaker Reservoir), may have been partially truncated by a channel that was subsequently filled by low-energy backfill deposits (inactive channel fill). A few miles east of Manila (control point 16), on the north side of the Uinta Mountains, a conglomeratic sandstone-filled channel cuts almost completely through the coastal sandstone. It seems that this period of downcutting, which occurred in about the same stratigraphic position in late middle Turonian time, is related to a lowering of base level, possibly eustatic lowering of sea level.

Following the time of downcutting, there was a rise in base level (relative sea-level rise), as indicated by an abrupt stratigraphic rise of the top of the coastal sandstone east of Steinaker Reservoir (between control points 8 and 9, plate 1, section $A-A^{\prime}$, and between control points 8 and 14 , plate 1 , section $C-C^{\prime}$ ), in the subsurface near Vernal (between control points 43 and 44, plate 1 , section $B-B^{\prime}$ ) on the south side of the Uinta Mountains, and in the subsurface east of Antelope Flat, probably east of Clay Basin, on the north side of the mountains (plate 1 , section $D-D^{\prime}$ ). It is difficult to differentiate nonmarine from marine deposits on the drill-hole logs between Antelope Flat and Vermillion Creek (control points 18 and 19 , respectively, plate 1 , section $\left.D-D^{\prime}\right)$; thus, the abruptness of the rise cannot be confirmed.

The amount of relative sea-level rise as indicated by the stratigraphic rise between control points 8 and 9 (plate 1, section $A-A^{\prime}$ ) and control points 8 and 14 (plate 1 , section $C-C^{\prime}$ ) on the south side of the Uinta 
Mountains is about $90 \mathrm{ft}(27 \mathrm{~m})$. On the north side of the mountains, east of Antelope Flat (plate 1, section $D-D^{\prime}$ ), the rise is probably about $70 \mathrm{ft}(21 \mathrm{~m})$. Data from this study indicate that the rise occurred during the latest middle Turonian or earliest late Turonian (between Western Interior molluscan fossil zones Prionocyclus hyatti and Prionocyclus macombi); however, more definitive biostratigraphic control on the south side of the Uinta basin and subsurface correlations along the east side of the basin to tie with the surface section at Blue Mountain (plate 1 , section $A-A^{\prime}$ ) indicate that the rise occurred in the earliest late Turonian (Molenaar, unpublished data). The progradation of the uppermost or last Frontier coastal sandstone was terminated by another relative sea-level rise and accompanying marine transgression that covered the subaerial plain throughout the study area. Assuming the water depth during deposition of the top of the thickest development of the offshore bar at the top of the Frontier (control point 9, plate 1 , section $\left.A-A^{\prime}\right)$ was at least $20 \mathrm{ft}(6 \mathrm{~m})$; the relative sea-level rise on the south side of the mountains was at least $100 \mathrm{ft}(30 \mathrm{~m})$. Similarly, on the north side of the mountains the rise was at least $60 \mathrm{ft}(18 \mathrm{~m})$, as measured at Chokecherry Draw (control point 17 , plate 1, section $\left.D-D^{\prime}\right)$. This rise occurred during early late Turonian time (molluscan fossil zone of Prionocyclus macombi). The sediment fill, represented by the upward-shallowing offshore bar, was deposited during later late Turonian time (molluscan fossil zones of Scaphites wareni and Scaphites whiffieldi), after the relative sea-level rise.

The amounts of the two relative sea-level rises are from measurements of compacted rocks; hence, differential compaction is not considered. In addition, the offshore bars on the north and south sides of the Uinta Mountains are assumed to be synchronous. Nevertheless, a suggestion can be made that, because the two relative sea-level rises were of a lesser magnitude on the north side of the Uinta Mountains than on the south side by factors of 77 percent for the earlier rise and 60 percent for the later rise, at least parts of the relative sea-level rises were caused by differential subsidence.

\section{REFERENCES CITED}

Cobban, W.A., and Kennedy, W.J., 1989, The ammonite Metengonoceras Hyatt, 1903, from the Mowry Shale (Cretaceous) of Montana and Wyoming: U.S. Geological Survey Bulletin 1787-L, in press.

Cobban, W.A., and Reeside, J.B., Jr., 1952, Frontier formation, Wyoming and adjacent areas: American Association of Petroleum Geologists Bulletin, v. 36, no. 10, p. 1913-1962.

Doelling, H.H., and Graham, R.L., 1972, Eastern and northern Utah coal fields-Vernal, Henry Mountains, Sego, La Sal-San Juan, Tabby Mountain, Coalville, Henrys Fork,
Goose Creek, and Lost Creek: Utah Geological and Mineral Survey Monograph Series 2, 409 p.

Eicher, D.L., 1965, Foraminifera and biostratigraphy of the Graneros Shale: Journal of Paleontology, v. 39, no. 5, p. 875-909.

Hale, L.A., 1962, Frontier Formation-Coalville, Utah and nearby areas of Wyoming and Colorado, in Enyert, R.L., and Curry, W.H., III, eds., Symposium on Early Cretaceous rocks of Wyoming: Wyoming Geological Association Annual Field Conference, 17th, Guidebook, p. 211-220.

1972, Depositional history of the Ferron Formation, central Utah, in Baer, J.L., and Callaghan, Eugene, eds., Plateau-Basin and Range transition zone, central Utah 1972: Utah Geological Association Publication 2, p. 29-40.

Hale, L.A., and Van de Graaff, F.R., 1964, Cretaceous stratigraphy and facies patterns; northeastern Utah and adjacent areas: Intermountain Association of Petroleum Geologists Annual Field Conference, 13th, Guidebook, p. 115-138.

Hansen, W.R., 1965, Geology of the Flaming Gorge area, Utah-Colorado-Wyoming: U.S. Geological Survey Professional Paper 490, 196 p.

Haq, B.U., Hardenbol, J., and Vail, P.R., 1987, Chronology of fluctuating sea levels since the Triassic: Science, v. 235, p. 1156-1166.

Kinney, D.M., 1955, Geology of the Uinta River-Brush Creek area, Duchesne and Uintah Counties, Utah: U.S. Geological Survey Bulletin 1007, 185 p.

Lickus, M.R., and Law, B.E., 1988, Structure contour map of the greater Green River basin, Wyoming, Colorado, and Utah: U.S. Geological Survey Miscellaneous Field Studies Map MF-2031, scale 1:500,000.

Maione, S.J., 1971, Stratigraphy of the Frontier Sandstone Member of the Mancos Shale (Upper Cretaceous) on the south flank of the eastern Uinta Mountains, Utah and Colorado: Wyoming Geological Association Earth Science Bulletin, v. 4, p. 27-58.

Merewether, E.A., 1983, The Frontier Formation and midCretaceous orogeny in the foreland of southwestern Wyoming: The Mountain Geologist, v. 20, no. 4, p. 121-138.

Merewether, E.A., Blackmon, P.D., and Webb, J.C., 1984, The mid-Cretaceous Frontier Formation near the Moxa arch, southwestern Wyoming: U.S. Geological Survey Professional Paper 1290, 29 p.

Merewether, E.A., and Cobban, W.A., 1986, Biostratigraphic units and tectonism in the mid-Cretaceous foreland of Wyoming, Colorado, and adjoining areas, in Peterson, J.A., ed., Paleotectonics and sedimentation in the Rocky Mountain region, United States, Part III, Middle Rocky Mountains: American Association of Petroleum Geologists Memoir 41, p. 443-467.

Obradovich, J.D., and Cobban, W.A., 1975, A time-scale for the Late Cretaceous of the Western Interior of North America, in Caldwell, W.G.E., ed., The Cretaceous System in the Western Interior of North America: 
Geological Association of Canada Special Paper 13, p. $31-54$.

Reeside, J.B., Jr., 1955, Revised interpretation of the Cretaceous section on Vermilion Creek, Moffat County, Colorado, in Anderman, G.G., ed., Green River Basin: Wyoming Geological Association Annual Field Conference, 10 th, Guidebook, p. 85-88.

Reeside, J.B., Jr., and Cobban, W.A., 1960, Studies of the Mowry Shale (Cretaceous) and contemporary formations in the United States and Canada: U.S. Geological Survey Professional Paper 355, 126 p.

Rowley, P.D., Hansen, W.R., Tweto, Ogden, and Carrara, P.E., 1985, Geologic map of the Vernal $1^{\circ} \times 2^{\circ}$ Quadrangle, Colorado, Utah, and Wyoming: U.S. Geological Survey Miscellaneous Investigation Series Map I-1526, scale 1:250:000.

Ryer, T.A., 1976, Cretaceous stratigraphy of the Coalville and Rockport areas, Utah: Utah Geology, v. 3, no. 2, p. 71-83.

1977, Age of Frontier Formation in north-central Utah: American Association of Petroleum Geologists Bulletin, v. 61 , no. 1 , p. $112-116$.

Ryer, T.A., and Lovekin, J.R., 1986, The Upper Cretaceous Vernal delta of Utah; depositional or paleotectonic feature?, in Peterson, J.A., ed., Paleotectonics and sedimentation in the Rocky Mountain region, United States, Part III, Middle Rocky Mountains: American Association of Petroleum Geologists Memoir 41, p. $497-510$.
Ryer, T.A., and McPhillips, Maureen, 1983, Early Late Cretaceous Paleogeography of east-central Utah, in Reynolds, M.W., and Dolly, E.D., eds., Mesozoic paleogeography of the west-central United States: Society of Economic Paleontologists and Mineralogists, Rocky Mountain Paleogeography Symposium, 2nd, p. 253-272.

Sears, J.D., 1924, Geology and oil and gas prospects of part of Moffat County, Colorado, and southern Sweetwater County, Wyoming: U.S. Geological Survey Bulletin 751-G, p. 269-319.

Sharp, J.V.A., 1963, Unconformities within basal marine Cretaceous rocks of the Piceance basin, Colorado: Boulder, University of Colorado, Ph.D. thesis, 170 p.

Stokes, W.L., and Madsen, J.H. Jr., 1961, Geologic map of Utah, northeast quarter: University of Utah College of Mines and Mineral Industries, scale 1:250,000.

Uyger, Kadir, and Picard, M.D., 1985, Mesozoic stratigraphy of Uinta Basin, northeast Utah, in Picard, M.D., ed., Geology and energy resources, Uinta Basin of Utah: Utah Geological Association Publication 12, p. 21-37.

Walton, P.T., 1944, Geology of the Cretaceous of the Uinta basin, Utah: Geological Society of America Bulletin, v. 55 , p. $91-130$.

Weimer, R.J., 1962, Late Jurassic and Early Cretaceous correlations, south-central Wyoming and northwestern Colorado, in Enyert, R.L, and Curry, W.H., III, eds., Symposium on Early Cretaceous rocks of Wyoming: Wyoming Geological Association Annual Field Conference, 17th, Guidebook, p. 124-130. 



WEST

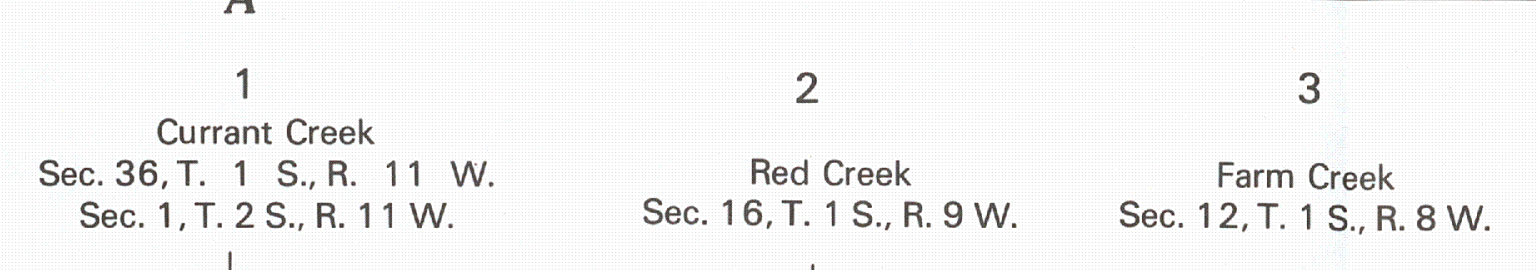

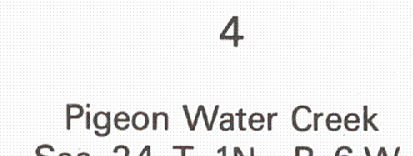

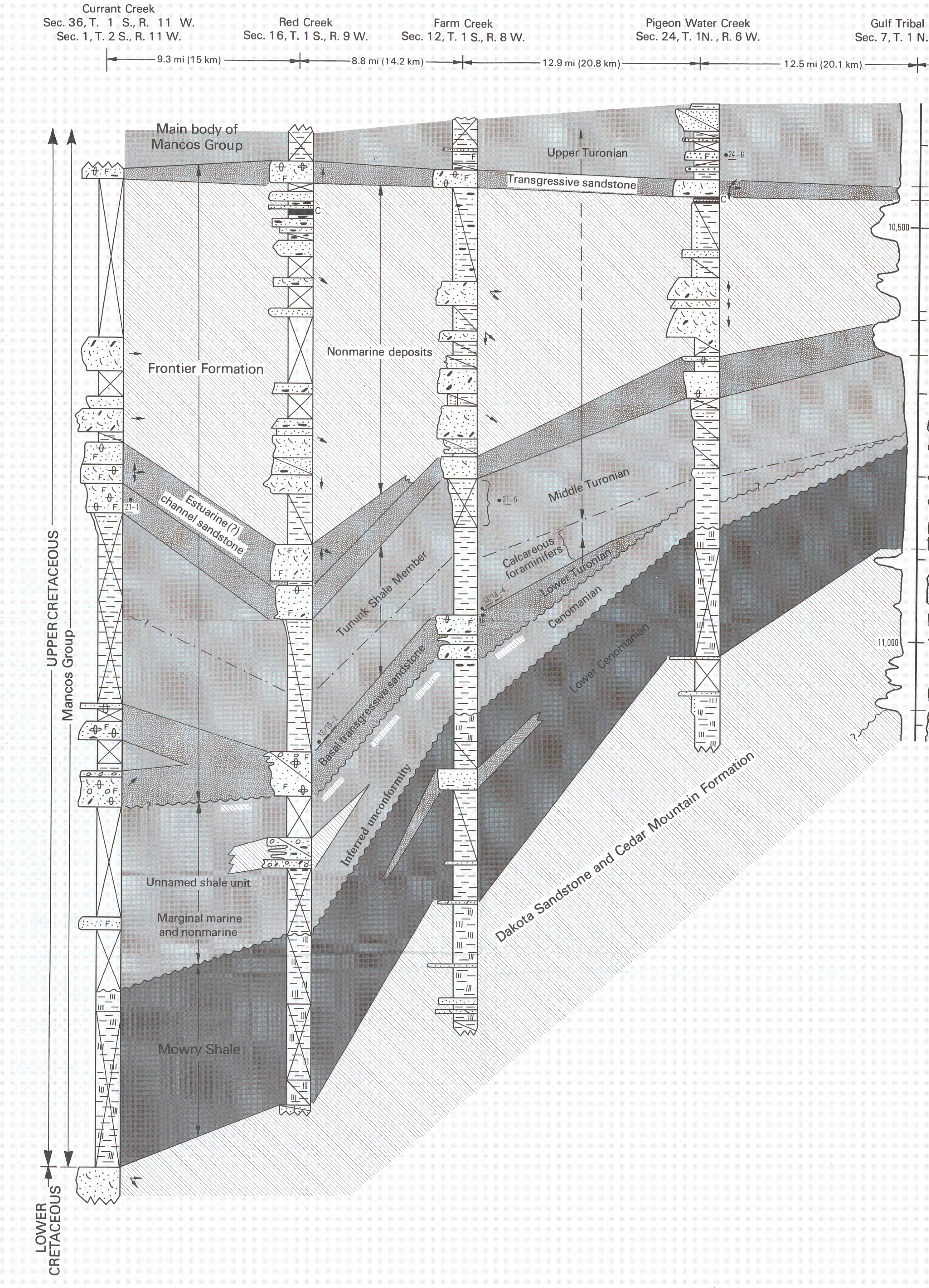

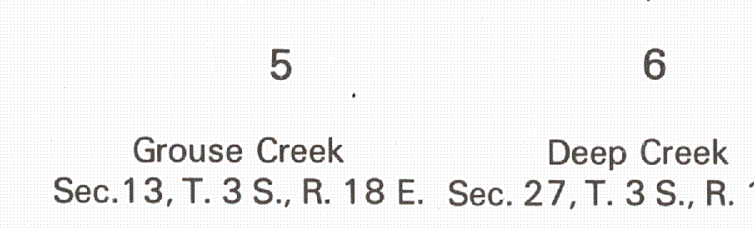

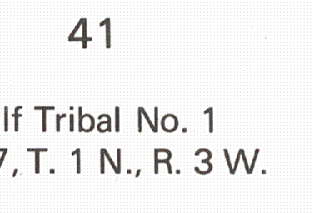

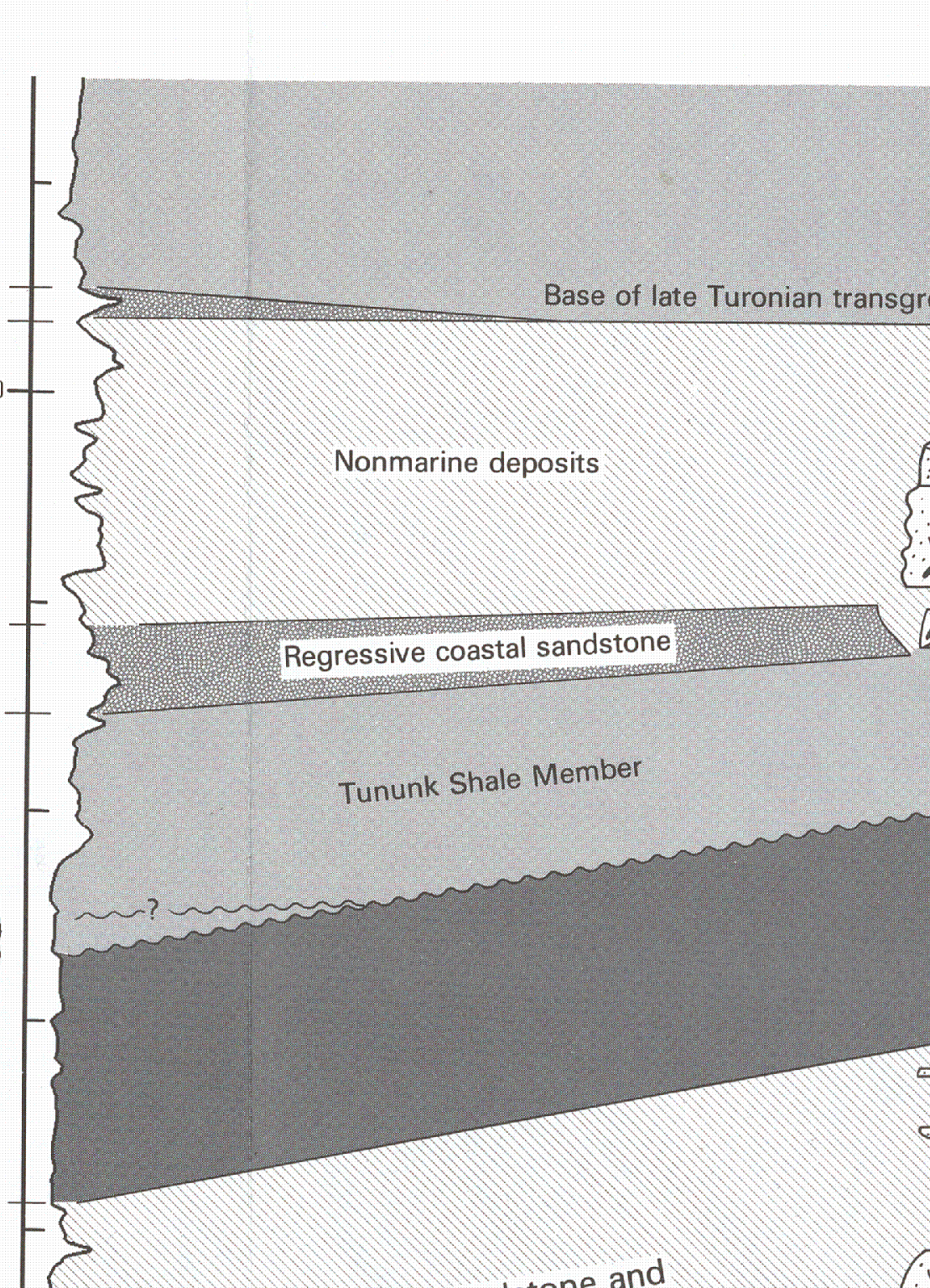

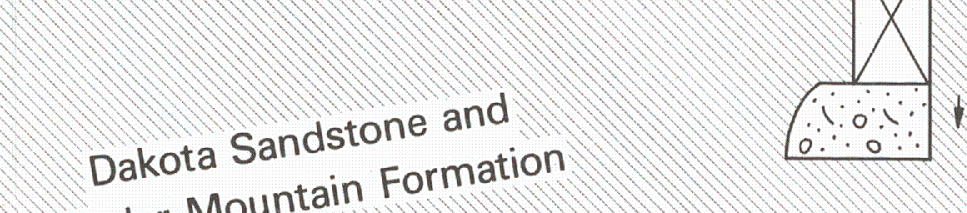

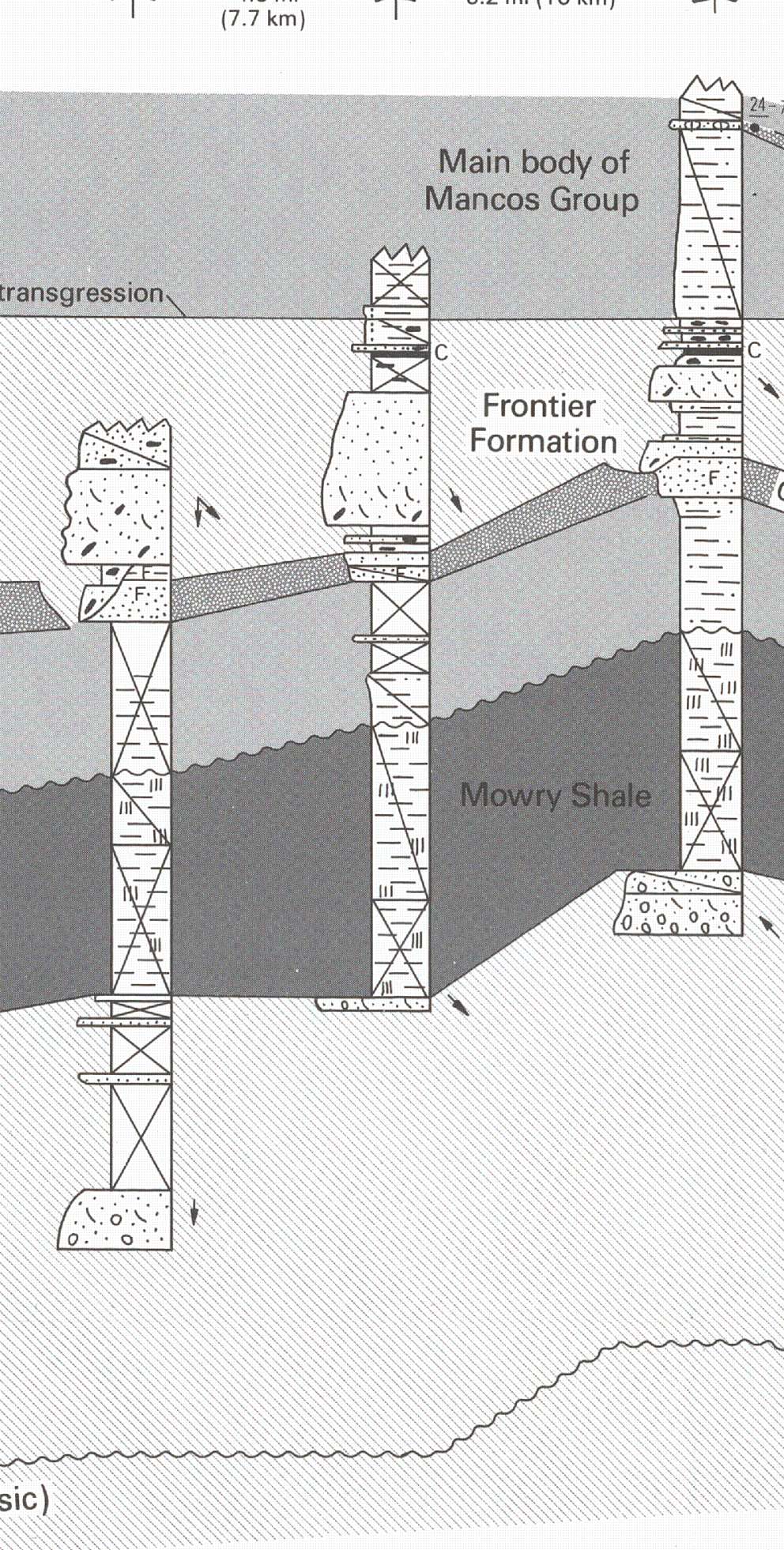

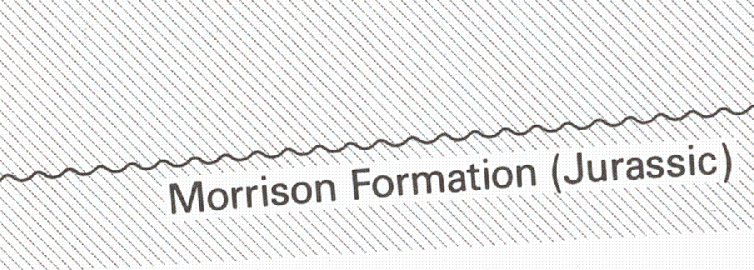
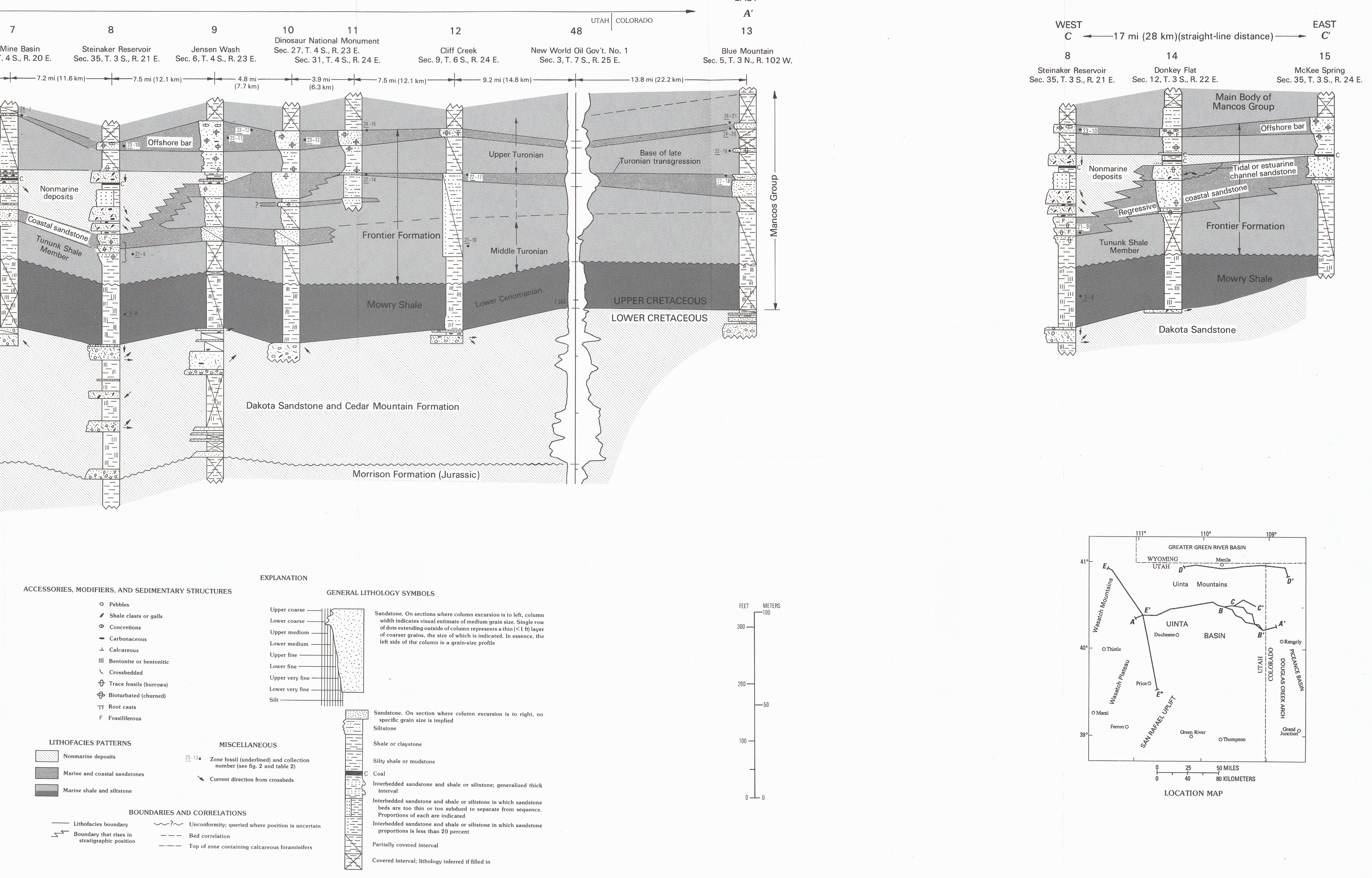

WEST

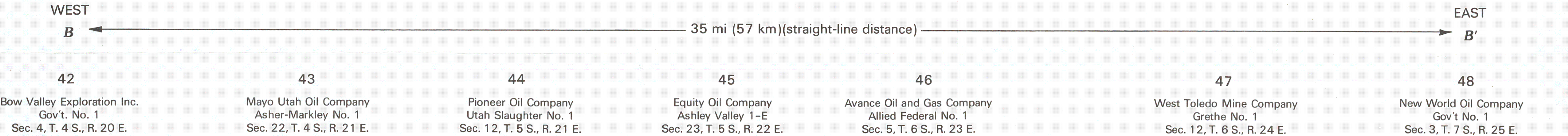

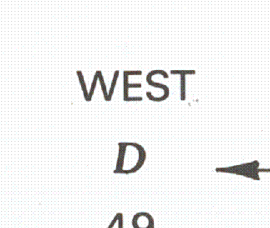

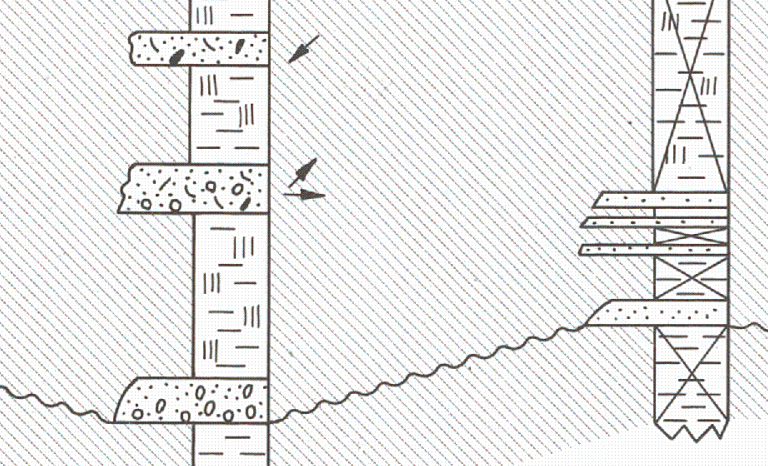

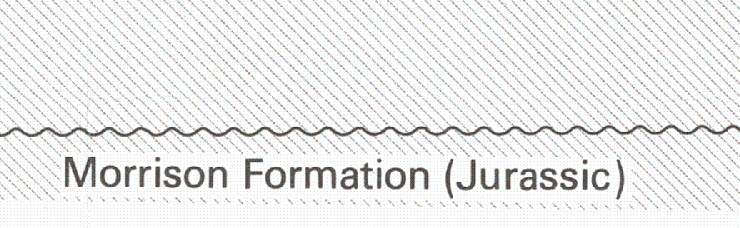

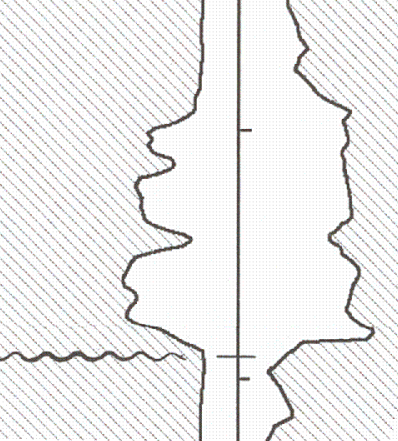
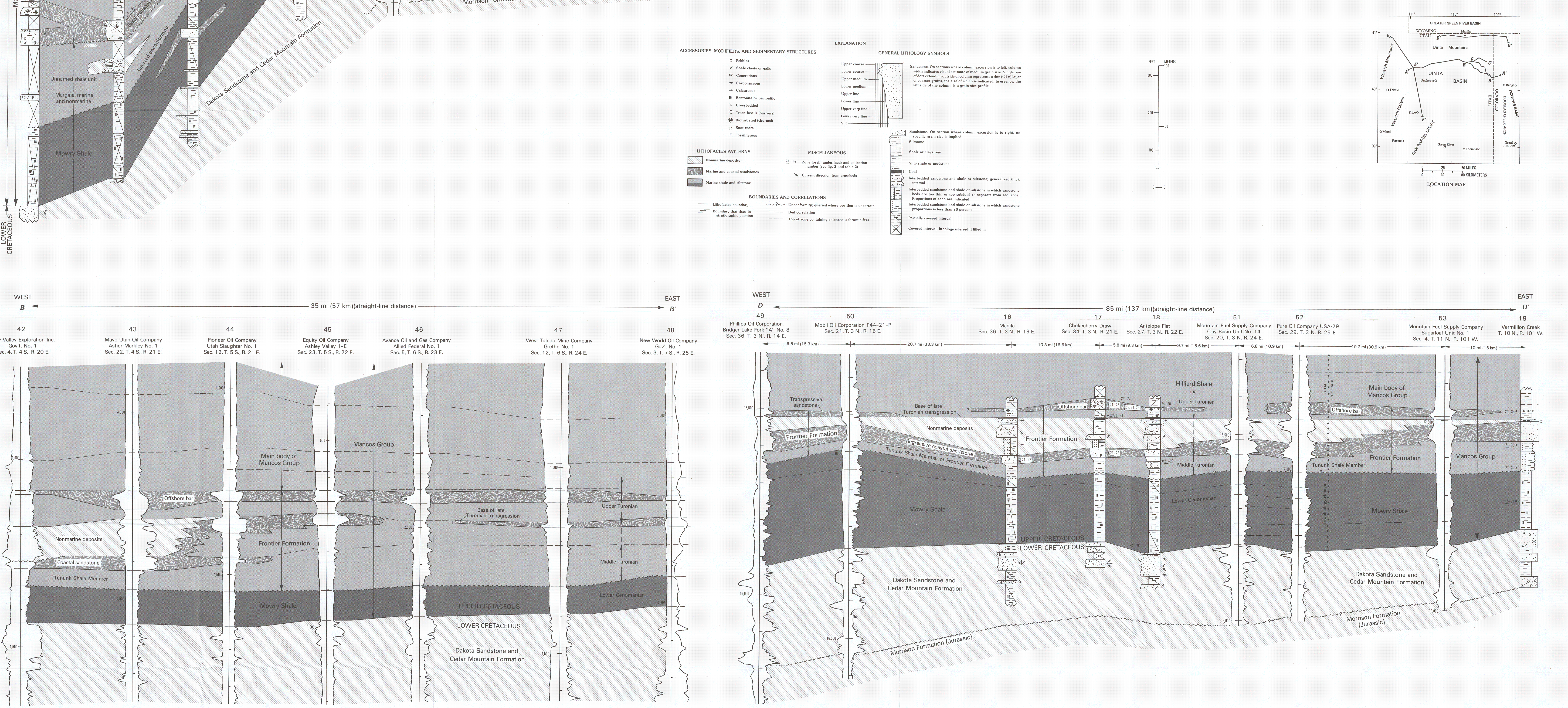

STRATIGRAPHIC CORRELATION SECTIONS OF THE FRONTIER FORMATION AND ASSOCIATED
MIDDLE CRETACEOUS ROCKS, NORTHEASTERN UTAH AND NORTHWESTERN COLORADO 
